$\begin{array}{llllllllll}M & A & T & E & R & \text { I } & \text { A } & \longleftarrow & Y\end{array}$

Krzysztof Lesiakowski

https://orcid.org/0000-0002-6176-6064

Uniwersytet Łódzki

\title{
Korupcja ludzi z ekipy Edwarda Gierka. Wspomnienia wiceprezesa NIK Władysława Piłatowskiego z lat 1980-1981
}

\begin{abstract}
Zarys treści: Tekst zawiera obszerne fragmenty wspomnień Władysława Piłatowskiego, wysokiego urzędnika Najwyższej Izby Kontroli (NIK). W latach 1980-1981 odegrał on wiodącą rolę w ujawnianiu przypadków nadużyć i praktyk korupcyjnych, których dopuścili sięl ludzie z szeroko rozumianej ekipy Edwarda Gierka. Za jego sprawą szczególnie nagłośniono sprawę nielegalnych inwestycji budowlanych. We wspomnieniach Piłatowski pokazuje własne spojrzenie na okoliczności podjęcia akcji kontrolnej, jej rozmaite meandry oraz następstwa upublicznienia wyników pracy inspektorów NIK. Abstract: The text contains large fragments of the memoirs by Władysław Piłatowski, a high official of the Supreme Audit Office (SAO). In 1980-81, he played a leading role in disclosing fraud and corruption practices committed by members of a broadly understood ruling team of Edward Gierek. He was instrumental in publicising the case of illegal building investments. In his memoirs, Piłatowski presents his own view of the circumstances leading to the inspection, its various meanders, and consequences of the making the results of the SOA inspectors public.
\end{abstract}

Słowa kluczowe: korupcja w Polsce, Najwyższa Izba Kontroli, Edward Gierek i jego współpracownicy, Polska Zjednoczona Partia Robotnicza 1980-1981, Władysław Piłatowski

Keywords: corruption in Poland, Supreme Audit Office, Edward Gierek and his cooperators, Polish United Worker’s Party 1980-81, Władysław Piłatowski

Gdy po strajkach z sierpnia 1980 r. powstawała „Solidarność”, bardzo mocno dały o sobie znać dążenia rozliczeniowe. W rodzącym się ruchu równolegle występowały motywy kontestacji i odnowy zastanego świata. Kolektywnej figurze ludu, uosabiającego siły dobra, przeciwstawiano polityczny establishment, skupiający jednostki pełniące rozmaite funkcje $\mathrm{z}$ nadania partyjnego, pod wieloma względami uprzywilejowane ${ }^{1}$. Na celowniku opinii społecznej znaleźli się tzw. prominenci, czyli osoby,

\footnotetext{
${ }^{1}$ S. Drelich, Postulaty gdańskie w kontekście założeń ludowego populizmu oddolnego, w: Czas przełomu. Solidarność 1980-1981, red. W. Polak, P. Ruchlewski, V. Kmiecik, J. Kufel, Gdańsk 2010, s. 23-24.
} 
które były związane z aparatem władzy. „W posierpniowych miesiącach ludzie domagali się rozliczeń" - stwierdziła dziennikarka i reportażystka Barbara Seidler, a ówczesny premier Józef Pińkowski potwierdził te słowa, mówiąc: „Płaciliśmy ciężki rachunek za tych, którzy sprawując różnorodne funkcje nie wykazali należytej skromności w swoim postępowaniu, ulegali różnym pokusom nieprawnie sięgając po dobra materialne, wykorzystywali w tym celu swoją pozycję służbową"”2.

Uwaga tysięcy Polaków koncentrowała się głównie na ludziach aparatu centralnego - których, stosując język opisu użyty w odniesieniu do zjawiska korupcji w amerykańskiej policji na początku lat siedemdziesiątych XX w. można nazwać tzw. mięsożernymi (meat eaters). Z czasem fala podejrzliwości schodziła też na niższe szczeble struktury władzy politycznej, państwowej, jak i zakładowej - tzw. roślinożernych (grass eaters) ${ }^{3}$. W różnych miejscach odzywały się głosy o potrzebie odebrania tym osobom dóbr nabytych w sposób nieuprawniony - zwykle były to działki budowlane i rekreacyjne, ale też talony na samochody osobowe itp. ${ }^{4}$ Społeczeństwo odreagowywało $w$ ten sposób swoje frustracje, wynikające z długotrwałych i narastających dotkliwych problemów z zaspokojeniem potrzeb materialnych. W tym zjawisku dawało się dostrzec zrozumiały i pożądany nurt oczyszczający, bo przecież osoby sprawujące funkcje wynikające z obowiązującego systemu nomenklatury specjalnie nie kryły się ze swoim uprzywilejowaniem w dostępie do często ekskluzywnych dóbr; nie można jednak zapominać, że „gniew ludu” miał w sobie także nurt destrukcyjny - bezrefleksyjne kierowanie niszczących podejrzeń, przed którymi w tamtych realiach trudno było się obronić.

Wszystko to oznaczało konieczność zmierzenia się przez społeczeństwo i aparat władzy $\mathrm{z}$ następstwami korupcji w kręgach rządzących. Istnieje wiele typów korupcji i pojęcie to rodzi trudności interpretacyjne, jednak niezależnie od przyjętej definicji należy podkreślić, że zjawisko to stanowi poważny problem ${ }^{5}$. Abstrahując od kontekstu kulturowego i historycznego, zawsze będzie ono miało komponent ekonomiczny, społeczny i polityczny ${ }^{6}$. Najogólniej rzecz ujmując

\footnotetext{
2 B. Seidler, Ludzie i paragrafy, Kraków 1988, s. 412; J. Pińkowski, 1980. Horyzont przed burza, Warszawa 1993, s. 95.

${ }^{3}$ Korupcja na przestrzeni wieków, Warszawa 2012, s. 83.

${ }^{4}$ Strajkująca na początku września 1980 r. załoga Zakładów Przemysłu Wełnianego „Tomtex” w Tomaszowie Mazowieckim domagała się odwołania prezydenta miasta m.in. z powodu wykorzystywania służbowego samochodu do celów prywatnych (wycieczki zagraniczne). Natomiast dyrektorom fabryki zarzucano opłacanie kosztów urządzania ich własnych mieszkań z funduszów zakładu oraz zatrudnianie na eksponowanych stanowiskach swoich kochanek! Zob. NSZZ „Solidarnośc" w regionie łódzkim $w$ dokumentach Stużby Bezpieczeństwa 1980-1981, oprac. S. Pilarski, R. Rabiega, Warszawa-Łódź 2010, s. 54-55.

${ }^{5}$ G. Makowski, Korupcja jako problem społeczny, Warszawa 2008, s. 17-18; R. Karklins, Wszystkiemu winien system. Korupcja w krajach postkomunistycznych, Warszawa 2009, s. 15-16.

${ }^{6}$ Światowa literatura dotycząca korupcji jest ogromna. Analizowane są rozmaite aspekty tego zjawiska, prawne, społeczne, nie brak też prac podejmujących problem korupcji w poszczególnych
} 
można powiedzieć, że: „Korupcja to nie tylko zepsucie czy akt brania łapówek, ale również naruszenie pewnych reguł społecznego podziału dóbr, za których przestrzeganie - na różnych szczeblach - jest się odpowiedzialnym"7. Zwykle będzie ona kojarzona z działalnością urzędników różnych szczebli, choć nie tylko. Bez względu na czas i formę występowania korupcji generalnie charakteryzuje ją jedna niezmienna cecha - koszty społeczne, w tym „nader często krzywda zwykłego człowieka"8. Wykorzystywanie stanowisk do celów prywatnych jest bowiem praktyką bezproduktywną, obliczoną na uzyskanie przewagi w podziale dóbr czy zysków (tzw. poszukiwanie renty), zmniejszającą efektywność gospodarowania i stanowi zachętę dla innych podmiotów do działania z naruszeniem prawa ${ }^{9}$. Stąd zwalczanie korupcji nie może być działaniem punktowym, inaczej mówiąc „nie wystarczy, aby prawo karne wykrywało i karało «zepsute jabłka»"10. Potrzebne są rozwiązania o szerszym charakterze, najlepiej systemowe.

Polska Rzeczpospolita Ludowa (PRL) doby początku lat osiemdziesiątych XX w. nie była zdolna do wdrożenia systemowych rozwiązań antykorupcyjnych, ale nowa ekipa, funkcjonująca od września 1980 r., zmuszona do walki o zwiększenie swojej wiarygodności zdecydowała się na ukaranie skorumpowanych „prominentów”. To oznaczało, że walka z korupcją zyskała legitymację ze strony władz politycznych. Z badań socjologicznych wynika jednak, że godząc się na rozliczenia we własnych szeregach, rządzący jednocześnie dążą do uruchomienia procesu konwersji tego problemu społecznego, polegającej na próbach pozbawienia go politycznego komponentu ${ }^{11}$. Tak też należy interpretować wspomnianą decyzję o uruchomieniu oficjalnych działań antykorupcyjnych. Możliwe jest również i to, iż polityczne centrum godząc się wdrożenie procedur zmierzających do ukarania winnych korupcji nie zdawało sobie sprawy ze skali zjawiska lub spodziewało się, że zostanie ono zawężone do wąskiego kręgu osób szczególnie skompromitowanych. Po uruchomieniu akcji rozliczeniowej musiała wzrosnąć rola instytucji śledczych

państwach bądź z perspektywy ogólnej. Zob. m.in. Corruption: the enemy within, ed. B. Rider, Hague-London-Boston 1999; M. Johnston, Syndromes of corruption. Wealth, power and democracy, Cambridge 2005; Democracy and corruption in Europe, eds D. Della Porta, Y. Mény, London-Washington 1997; D. Antonić, Corruption in Serbia, Belgrade 2006.

${ }^{7}$ S. Rose-Ackerman, Korupcja i rzady, Warszawa 2001, s. 8 [Wstęp do wydania polskiego]. W podobny sposób zdefiniował korupcję historyk Krzysztof Madej, Siermiężna i dolarowa korupcja w PRL w latach 1956-1980, w: PRL. Trwanie i zmiana, red. D. Stola, M. Zaremba, Warszawa 2003, s. 250.

${ }^{8}$ Korupcja na przestrzeni..., s. 5. Niektórzy autorzy traktują korupcję nawet jako „pogwałcenie praw człowieka, a w skrajnym wypadku, jako "przestępstwo przeciwko ludzkości»", zob. I.F.I. Shihata, Corruption - a general review with an emphasis on the role of the World Bank, w: Corruption: the enemy..., s. 260.

${ }^{9}$ S. Rose-Ackerman, op. cit., s. 35.

${ }^{10}$ Ibidem, s. 407.

${ }^{11}$ G. Makowski, op. cit., s. 91. 
i kontrolnych, w tym prokuratur, komisji kontroli partyjnej, ale też aparatu kontroli państwowej, na czele którego stała Najwyższa Izba Kontroli. To do niej zaczęły napływać tysiące skarg i wniosków o przeprowadzenie inspekcji, z którymi przybywały delegacje pracownicze z różnych części Polski. Stąd reakcją aparatu władzy, dążącego do swoistego skanalizowania wzrastającej fali rozliczeniowej, była zapowiedź upoważnienia NIK do zbadania zgłaszanych spraw. Formalną odpowiedzią na nowe wyzwania miała być zmiana ustawy o działalności Izby z października 1980 r., która zwiększała jej samodzielność i uprawnienia w dziedzinie planowania i prowadzenia kontroli. Poza tym odbywające się w październiku VI Plenum KC Polskiej Zjednoczonej Partii Robotniczej (PZPR) podjęło specjalną uchwałę, zobowiązującą NIK i organy kontroli finansowej państwa do zbadania legalności realizowanych w Polsce (poza wsią) prywatnych inwestycji budowlanych ${ }^{12}$.

W tej sytuacji nie sposób badać problematyki rozliczeń ekipy Edwarda Gierka, jak i szerzej rzecz ujmując przestępczości gospodarczej, bez odwołania się do źródeł wytworzonych przez kontrolerów $\mathrm{NIK}^{13}$. Oficjalne materiały pokontrolne, a tym bardziej te, które przeniknęły do ówczesnej prasy, zdecydowanie nie wyczerpują możliwości poszerzenia poznania historycznego w odniesieniu do zjawiska nadużyć i korupcji, w które byli uwikłani „prominenci” różnych szczebli. W tym względzie przydatne mogą być także źródła o charakterze wspomnieniowym, wytworzone przez byłych pracowników aparatu kontroli państwowej. Stąd szczególną uwagę należy poświęcić wspomnieniom autorstwa Władysława Piłatowskiego, w okresie nasilenia akcji rozliczeniowej wiceprezesa NIK, delegowanego do koordynowania działań sprawdzających w odniesieniu do skarg obywateli na ludzi władzy, sprawozdawcy ustaleń kontrolnych na forum IX Nadzwyczajnego Zjazdu PZPR w lipcu 1981 r., postrzeganego przez wielu aktywistów partyjnych jako osoba odpowiedzialna za osłabianie pozycji PZPR i oczernianie wizerunku jej działaczy.

Władysław Piłatowski urodził się w 1925 r. w Konotopie (gmina Ożarów Mazowiecki), a zmarł w 2007 r. w Warszawie. W latach 1942-1943 był więziony w Malborku, a następnie wywieziono go na roboty przymusowe do Niemiec, gdzie pracował w majątku rolnym. Po wojnie był traktorzystą w Państwowym Przedsiębiorstwie Traktorów i Maszyn Rolniczych w Jaworze na Dolnym Śląsku (1946-1947). Przez następne trzy lata pracował jako majster, a później mistrz warsztatowy w Traktorowym Ośrodku Rolnym we wspomnianym Jaworze. Z dostępnych danych wynika, że od 1946 r. był członkiem Polskiej Partii Robotniczej (PPR), a od 1948 r. PZPR. W 1950 r. skierowano go do Wojewódzkiej Szkoły Partyjnej we Wrocławiu, po czym w następnym roku został kierownikiem

${ }^{12}$ VI Plenum KC PZPR 5-6 IX (I część), 4-6 X (II część) 1980, Warszawa 1980, s. 50, 60.

${ }^{13}$ Szeroko z nich korzystał autor najważniejszego opracowania dotyczącego wspomnianej problematyki Jakub Szumski (Rozliczenia z ekipa Gierka 1980-1984, Warszawa 2018). Zob. też: K. Madej, Bezradność lub represja. Władze wobec przestępczości gospodarczej w PRL (1956-1960), Warszawa 2010. 
wydziału w Państwowym Ośrodku Maszynowym w Złotoryi. W latach 1954-1956 znów był na szkoleniu - tym razem w Centralnej Szkole Partyjnej przy Komitecie Centralnym (KC) PZPR ${ }^{14}$. Jego kariera przyspieszyła w $1956 \mathrm{r}$. Został wtedy I sekretarzem Komitetu Powiatowego partii w Jeleniej Górze, którą to funkcję sprawował do $1957 \mathrm{r}$. Wtedy powołano go na stanowisko przewodniczącego Wojewódzkiej Komisji Kontroli Partyjnej we Wrocławiu, a w 1960 r. został sekretarzem organizacyjnym w Komitecie Wojewódzkim (KW) PZPR. W październiku 1963 r. kolejny raz awansowal - tym razem na stanowisko I sekretarza wrocławskiego komitetu wojewódzkiego. Na IV Zjeździe PZPR wybrano go do składu KC (wcześniej był zastępcą) ${ }^{15}$. Jako działacz partyjny szczebla wojewódzkiego, Piłatowski był kojarzony z sekretarzami uznawanymi za bliskich środowisku skupionemu wokół gen. Mieczysława Moczara. W latach 1965-1972 był posłem. Do NIK trafił w $1971 \mathrm{r}$. i tu przez lata sprawował funkcję dyrektora generalnego. W listopadzie 1980 r., gdy zaczynała się akcja rozliczeniowa, został wiceprezesem NIK ${ }^{16}$.

Publikowany poniżej materiał, zatytułowany „Kilka uwag na temat mojej znajomości i współpracy z gen. Mieczysławem Moczarem”, pochodzi z obszernego załącznika do listu (rękopis, 73 karty formatu A4), który Piłatowski skierował do autora poniższego tekstu z datą 6 IV 1994 r. Korespondencja ta była odpowiedzią na prośbę o podzielenie się refleksjami historycznymi, dotyczącymi prezesa NIK w latach 1971-1983, którym był wspomniany gen. Moczar. Pojedyncze informacje zaczerpnięte z listu Piłatowskiego zostały wykorzystane w książce o „Mietku”17. Zdecydowana większość pozostała niezagospodarowana i w zasadzie na długie lata zapomniana. Kierując się jednak intencją poszerzenia poznania historycznego, w tym zgłębiania obrazu mechanizmów, które uwidoczniły się w czasie rozliczania „ludzi Gierka”, częściowo mających przecież charakter uniwersalny, warto ten materiał źródłowy wydobyć na światło dzienne.

Należy zaznaczyć, że publikowane są obszerne, ale wybrane fragmenty wspomnianego załącznika do listu - ok. 60\% tekstu wyjściowego. Pominięto kwestie, które wprost nie były związane z tematyką rozliczeniową - opis początków kariery Piłatowskiego, nawiązania do charakteru znajomości z Moczarem, ogólne informacje na temat funkcjonowania NIK itp. Należy jeszcze dodać, że całość materiału została opracowana redakcyjne i językowo, dodano akapity (nie było

\footnotetext{
${ }^{14}$ Mimo nazwy oraz zamiarów nadania tej placówce rangi szkoły wyższej, nawet po jej przeniesieniu z Łodzi do Warszawy, niezmiennie była ona szkołą dla aktywu partyjnego średniej rangi; zob. B. Cichocki, K. Jóźwiak, Najważniejsze sa kadry. Centralna Szkoła Partyjna PPR/PZPR, Warszawa 2006, s. 194.

${ }^{15}$ https://katalog.bip.ipn.gov.pl/informacje/1816 (dostęp: 27 III 2020).

${ }^{16}$ Po raz pierwszy jako wiceprezes wziął udział w posiedzeniu Kolegium NIK 17 listopada $1980 \mathrm{r}$. Zob. Archiwum Najwyższej Izby Kontroli (dalej: ANIK), Departament Prezydialny (dalej: DP), 126/1, Protokół posiedzenia Kolegium NIK, Warszawa, 17 XI 1980 r., k. 177.

${ }^{17}$ K. Lesiakowski, Mieczysław Moczar „Mietek”. Biografia polityczna, Warszawa 1998, s. 430.
} 
ich w oryginale), poprawiono ewidentne pomyłki. Wszelkie większe ingerencje $\mathrm{w}$ tekst zostały odpowiednio oznaczone $\mathrm{e}^{18}$.

Publikowane źródło należy traktować jako materiał wspomnieniowy tzw. wywołany. Ma tutaj też zastosowanie określenie, używane czasem w odniesieniu do korespondencji, „pamiętnik mimo woli”. Posiada ono duży walor poznawczy, co dla badaczy sięgających po tego rodzaju źródła ma zwykle pierwszorzędne znaczenie $^{19}$. Trzeba jednak podkreślić - przyznał to sam Piłatowski - że podczas przygotowywania rękopisu sięgał on do dostępnych mu notatek z zebrań i narad, także kierownictwa NIK, szczególnie jeśli chodzi o liczby obrazujące działalność kontrolną Izby. Nie zmienia to jednak w żadnej mierze oceny, że mamy do czynienia $\mathrm{z}$ osobistym świadectwem (tzw. egodokument) osoby bezpośrednio zaangażowanej w kreowanie ważnych wydarzeń historycznych. Oczywiście nie oznacza to, że jest to źródło w pełni obiektywne. Każdy materiał o charakterze wspomnieniowym, obok autopsji, cechuje zwykle duży ładunek subiektywizmu. $\mathrm{Na}$ jego wartość rzutuje również fakt, że rękopis powstał ex post $\mathrm{w}$ odpowiedzi na konkretną prośbę, a zatem można tu mówić o motywacji kierowanej, która jest uznawana za mniej cenną niż motywacja osobista. W związku z tym tekst Piłatowskiego, jak każde źródło, wymaga dogłębnej krytyki. Trzeba jednak mieć na uwadze to co napisał Zbysław Wojtkowiak, badacz zajmujący się metodologicznymi rozważaniami nad walorami memuarystyki, który trafnie zauważył, że pamiętnik może zawierać informacje znane tylko danemu autorowi, a to czyni bezowocnym weryfikowanie uzyskanych informacji poprzez konfrontowanie z innymi przekazami, jednocześnie podkreślając, że nie zwalnia to historyka z krytyki wiarygodności tego źródła ${ }^{20}$.

„Nikt nie widzi wszystkiego, każdy przechodzi obok mnóstwa rzeczy, których nigdy nie zauważy, ponieważ jego umysł od razu je odpiera, zdążając ku temu co go zajmuje" - napisał przywoływany powyżej autor, sięgając po słowa Jana Parandowskiego ${ }^{21}$. Podobnie rzec można o wspomnieniach Piłatowskiego. On także nie widział wszystkiego, bo to przecież nie jest możliwe, i nie o wszystkim - także $\mathrm{z}$ wielu innych powodów - napisał. Nie unikał przy tym subiektywnych ocen, zdarzyły mu się też błędy rzeczowe ${ }^{22}$, ale paradoksalnie ten aspekt wzmacnia autentyczność jego tekstu, choć dla historyka może stwarzać dodatkową trudność

\footnotetext{
${ }^{18}$ Korzystano $\mathrm{w}$ tym względzie $\mathrm{z}$ rozwiązań wskazywanych przez specjalistyczną literaturę; zob.

Ł. Garbal, Edytorstwo. Jak wydawać współczesne teksty literackie?, Warszawa 2011, s. 40-51.

${ }^{19}$ S. Skwarczyńska, Teoria listu, oprac. E. Feliksiak, M. Leś, Białystok 2006, s. 332.

${ }^{20}$ Z. Wojtkowiak, Źródła narracyjne, cz. 1: Pamiętnik, tekst literacki, Poznań 2003, s. 55-57.

${ }^{21}$ Ibidem, s. 61.

22 Przykładowo Piłatowski błędnie wiązał objęcie przez Moczara funkcji prezesa NIK (22 czerwca 1971 r.) z decyzjami VI Zjazdu PZPR (grudzień 1971 r.). Formalnego wyboru nowego zwierzchnika Izby dokonał Sejm, na wniosek Klubu Poselskiego PZPR; zob. Pierwszy dzień obrad posiedzenia plenarnego Sejmu. Zmiany na stanowiskach państwowych, „Trybuna Robotnicza”, 23 VI 1971 r., s. 1-2.
} 
$\mathrm{w}$ korzystaniu. Mamy zatem w omawianym przypadku do czynienia $\mathrm{z}$ realnym źródłem historycznym, ze wszystkimi jego zaletami i wadami. W znacznej mierze potwierdzającym swoją treścią słowa Marie Mendras, francuskiej badaczki zajmującej się problematyką rosyjską, że „korupcja w nomenklaturze partii komunistycznej stała się integralną częścią systemu"23.

* * *

\section{Wspomnienia Władysława Piłatowskiego}

$[\ldots]^{24}$

Następnego dnia [chodzi najpewniej o początek czerwca 1971 r. - przyp. KL] dowiedziałem się od zastępcy kierownika Wydziału Spraw Sejmowych KC, że Moczar $^{25}$ jest już po rozmowie z członkami kierownictwa partii. Mój rozmówca powiedział mi, że Edward Babiuch ${ }^{26}$ i Jan Szydlak ${ }^{27}$ wystąpili do Edwarda Gierka ${ }^{28}$ z wnioskiem, aby Moczar objął stanowisko Prezesa NIK. Wiadomość ta bardzo

${ }^{23}$ M. Mendras, Rule by bureaucracy in Russia, w: Democracy and corruption..., s. 122.

${ }^{24}$ Pominięto wstępne informacje, dotyczące nawiązania przez Piłatowskiego znajomości z Moczarem - w końcu 1956 r. w warszawskim gabinecie Ignacego Logi-Sowińskiego, wtedy przewodniczącego Centralnej Rady Związków Zawodowych (CRZZ).

${ }^{25}$ Mieczysław Moczar (1913-1986) - polityk komunistyczny, generał dywizji. Przed 1939 r. więziony za działalność komunistyczną, po wybuchu wojny współpracował z sowieckim wywiadem wojskowym, od 1941 r. w podziemiu na terenie okupowanej Polski - w Gwardii Ludowej i Armii Ludowej. W latach 1945-1948 wysoki funkcjonariusz aparatu bezpieczeństwa, następnie odsunięty na boczny tor. Od 1956 r. ponownie w resorcie, najpierw jako wiceminister, a w latach 19641968 minister spraw wewnętrznych. Członek PPR i PZPR, sekretarz KC 1968-1971, zastępca członka Biura Politycznego 1968-1971, członek Biura Politycznego 1970-1971 i 1980-1981, prezes NIK 1971-1983, członek Rady Państwa 1969-1976, członek Rady Ministrów 1976-1981. Poseł na Sejm 1957-1980, prezes Zarządu Głównego (ZG) Związku Bojowników o Wolność i Demokrację 1964-1972, prezes Rady Naczelnej tego związku 1980-1983. K. Lesiakowski, „Mietek"..., passim.

${ }^{26}$ Edward Babiuch (ur. 1927) - polityk komunistyczny. W latach 1949-1955 w aparacie Związku Młodzieży Polskiej (ZMP), redaktor naczelny „Życia Partii” 1963-1965, kierownik Wydziału Organizacyjnego KC, sekretarz KC 1970-1980, zastępca przewodniczącego Rady Państwa 19761980, premier w okresie luty-sierpień 1980. Poseł na Sejm 1969-1980. W lipcu 1981 r. usunięty z PZPR, internowany po wprowadzeniu stanu wojennego. T. Mołdawa, Ludzie władzy 1944-1991. Władze państwowe i polityczne Polski według stanu na dzień 28 II 1991, Warszawa 1991, s. 330.

27 Jan Szydlak (1925-1997) - polityk komunistyczny. Sekretarz ZG ZMP 1954-1957, I sekretarz KW PZPR w Poznaniu 1960-1968, sekretarz KC 1968-1977, członek Biura Politycznego 1970-1980, przewodniczący CRZZ (1980), wicepremier 1976-1980. Poseł na Sejm 1961-1980. Wykluczony z PZPR w lipcu 1981 r., internowany po wyprowadzeniu stanu wojennego. Ibidem, s. 430.

${ }^{28}$ Edward Gierek (1913-2001) - polityk komunistyczny. W latach 1923-1934 i 1937-1948 emigrant we Francji i Belgii, I sekretarz KW PZPR w Katowicach 1957-1970, członek Biura Politycznego KC 1956 i 1959-1980, I sekretarz KC 1970-1980, usunięty z PZPR w lipcu 1981 r., internowany po wprowadzeniu stanu wojennego. Poseł na Sejm 1952-1980. Ibidem, s. 353. 
mnie ucieszyła. Wiedziałem też, że aparat, zwłaszcza kadra kierownicza w NIK dobrze przyjmie nowego szefa. To wśród niej właśnie od dłuższego czasu narastały krytyczne uwagi, iż łączenie przez Zenona Nowaka ${ }^{29}$ dwóch funkcji - Prezesa NIK i Przewodniczącego Centralnej Komisji Kontroli Partyjnej [CKKP] miało nie najlepszy wpływ na prawidłowe funkcjonowanie aparatu kontroli. Szeroką krytykę, zwłaszcza w jednostkach kontrolowanych, budziły niewłaściwe metody pracy części kadry kontrolującej, nadmierny formalizm polegający na mechanicznym mnożeniu przykładów niezgodnych z przepisami, bez głębszej analizy całokształtu zachodzących procesów gospodarczych i osiąganych końcowych wyników ekonomicznych przez jednostkę kontrolowaną. Ostrej krytyce poddawano zanik wrażliwości inspektorów na istnienie nadmiernej ilości przepisów, nierzadko wzajemnie się wykluczających, krępujących inicjatywę kadry zarządzającej gospodarką. Kontrola powinna ujawniać tego typu zjawiska, dokumentować je oraz postulować ich zmiany. Z punktu widzenia praktyki kontrolerskiej takie podejście było o wiele łatwiejsze i mniej ryzykowne. W efekcie prowadzić to musiało do podejmowania kontroli wycinkowych, drobnych, kosztem zmniejszania liczby kontroli problemowych, kompleksowych. Bardziej całościowo oceniających końcowe wyniki ekonomiczne osiągane przez jednostki kontrolowane. Większa część kadry kierowniczej zdawała sobie sprawę z tych słabości i podejmowała wysiłki, by temu zaradzić. Podejmowane poczynania zmierzające do unowocześnienia metod kontroli natrafiały na nadmierną powściągliwość i ostrożność ze strony ówczesnego prezesa NIK - Zenona Nowaka. Wprawdzie udzielał on ostrożnego poparcia tym poczynaniom, ale było to raczej poparcie werbalne. Niemniej otworzyło ono drogę do podjęcia w dwóch departamentach: Prezydialnym i Koordynacji ${ }^{30}$ - prac studyjnych nad opracowaniem nowych przepisów regulujących pracę jednostek organizacyjnych NIK oraz jej funkcje koordynacyjne w odniesieniu do innych organów kontroli, inspekcji i lustracji. $[\ldots]^{31}$

$\mathrm{Z}$ całą konsekwencją łamiąc stereotypy i nie najlepsze przyzwyczajenia części kadry inspektorskiej, z roku na rok osiągaliśmy znaczny wzrost wydajności pracy

${ }^{29}$ Zenon Nowak (1905-1980) - polityk komunistyczny. Członek KC Komunistycznej Partii Polski 1932-1938, w obozie pracy 1942-1945, w Armii Radzieckiej 1945-1947, kierownik Wydziału Personalnego/Kadr KC PPR a następnie PZPR 1948-1950, sekretarz KC 1950-1954, wicepremier 1952-1968, prezes NIK 1968-1971, ambasador w ZSRR 1971-1978. Poseł na Sejm 1952-1956, 1961-1971. Ibidem, s. 403.

${ }^{30}$ W 1971 r. struktura organizacyjna centrali NIK obejmowała: Departament Koordynacji, Departament Prezydialny i Departament Administracyjno-Gospodarczy oraz 15 wyspecjalizowanych zespołów kontrolnych m.in. Administracji i Gospodarki Komunalnej, Budownictwa i Przemysłu Materiałów Budowalnych, Budżetu Państwa i Finansów, Górnictwa i Energetyki, Przemysłu Ciężkiego i Maszynowego, Rolnictwa i Leśnictwa. ANIK, DP, 1543/11, Protokół posiedzenia Kolegium NIK, Warszawa, 5 VIII 1971 r., k. 3-4.

${ }^{31}$ Pominięto fragment dotyczący kwestii organizacyjnych związanych z przejęciem stanowiska prezesa NIK przez Moczara. 
mierzony ilością jednostek, w których przeprowadzono kontrolę, dla przykładu: w 1970 r. kontrolą objętych było 4073 jednostek, w tym 454 jednostki objęte zostały kontrolą sprawdzającą; w 1975 r. kontrola objęła 5691 jednostek, w tym w 728 jednostkach przeprowadzono kontrole sprawdzające.

Znacznie wzrosła liczba opracowań zbiorczych w oparciu o materiały z kontroli: w 1970 r. sporządzono 299 opracowań zbiorczych, [a] w 1975 r. sporządzono 466 opracowań zbiorczych. Ministrowie i kierownicy urzędów centralnych z każdym rokiem otrzymywali również coraz więcej informacji i ważniejszych opracowań zbiorczych z kontroli, np.: o ile w 1970 r. otrzymali oni 136 ważniejszych opracowań pokontrolnych, to w 1975 r. otrzymali już 275. Natomiast Prezes Rady Ministrów, wicepremierzy otrzymywali średnio w roku 100 opracowań z najważniejszych dla funkcjonowania kraju dziedzin gospodarki. Znacznie poprawiła się merytoryczna wartość opracowań zbiorczych i wniosków pokontrolnych oraz ich przydatność dla potrzeb Sejmu, rządu, poszczególnych ministerstw. Dawali temu wyraz: Marszałek Sejmu, Przewodniczący Rady Państwa, Prezes Rady Ministrów oraz ministrowie - przesyłając na ręce prezesa NIK pisma, w których dziękując za przesłane im materiały, wysoko oceniali ich przydatność dla usprawnienia procesów zarządzania.

Tak więc w wyniku coraz bardziej ofensywnej i skutecznej działalności NIK, stopniowo zmieniała się atmosfera społeczna wokół niej. Zdobywała ona szerokie kręgi sojuszników dla swej działalności w różnych środowiskach, rósł jej autorytet i zaufanie społeczeństwa. Dlatego też z tym większym zdziwieniem, zarówno społeczeństwo, jak i my pracownicy NIK-u przyjęliśmy inicjatywę Prezesa Rady Ministrów Piotra Jaroszewicza ${ }^{32}$, aby NIK została podporządkowana pod jego nadzór ${ }^{33}$. Mimo licznych listów i protestów kierowanych przez różne środowiska i osoby do Sejmu i KC, Biuro Polityczne inicjatywę premiera poparło, a Sejm w dniu 27 marca 1976 r. dokonał odpowiednich zmian w Konstytucji i uchwalił nową ustawę o NIK. W ustawie tej zobowiązano NIK do nakładania kar pieniężnych na osoby, które dopuściły się różnych przewinień. I tak powołana ustawa w artykule 15 ust. 1 określała wysokość tych kar. Inspektor mógł

32 Piotr Jaroszewicz (1909-1992) - żołnierz Wojska Polskiego (WP) i polityk komunistyczny. W wojsku od 1943 r., wiceminister obrony narodowej w latach 1945-1950, zastępca przewodniczącego Państwowej Komisji Planowania Gospodarczego 1950-1952, wicepremier 1952-1970, członek Biura Politycznego KC PZPR 1964-1980, premier rządu 1970-1980. Poseł na Sejm 1947-1980. W 1981 r. usunięty z PZPR, internowany po wprowadzeniu stanu wojennego, zamordowany wraz z żoną we własnym domu w niewyjaśnionych okolicznościach w nocy z 31 sierpnia na 1 września 1992 r. T. Mołdawa, op. cit., s. 364.

${ }^{33} \mathrm{~W}$ formie adekwatnej do realiów politycznych epoki protestowało też kierownictwo NIK, stwierdzając, że ograniczenie niezależności Izby „,spowoduje, jak można przypuszczać zubożenie możliwości uzyskiwania informacji o faktycznym przebiegu realizacji dyrektyw i uchwał kierownictwa Partii”, zob. ANIK, DP, 1543/13, Towarzysz Jan Szydlak, członek Biura Politycznego PZPR, Warszawa, luty 1972 r., k. [1]. 
nałożyć karę w wysokości 5 tys. zł, dyrektor zespołu, departamentu i delegatury - 10 tys. zł, a prezes - 25 tys. zł ${ }^{34}$. W ten oto sposób usiłowano przekształcić NIK z najwyższego organu kontroli państwowej w jeszcze jeden organ ścigania. Trzeba przyznać, że pracownicy NIK z ogromną niechęcią odnieśli się do tego ustawowego obowiązku i w nielicznych przypadkach uciekali się do nakładania kar pieniężnych ${ }^{35}$. A prezes Moczar nie nałożył ani jednej kary pieniężnej.

Podporządkowanie NIK pod nadzór premiera usiłowano tłumaczyć społeczeństwu, że chodzi tu o uczynienie z niej bardziej operatywnej instytucji, szerzej angażującej się w sprawy bardziej przydatne dla sprawniejszej pracy rządu. W istocie u podstaw tej decyzji legły motywy czysto polityczne. Chodziło głównie o to, aby ograniczyć kontrolne funkcje Sejmu, a tym samym osłabić jego wpływ na rząd i na kształtowanie się sytuacji w państwie. $Z$ drugiej strony chodziło również o to, aby ograniczyć względną samodzielność NIK w określaniu kierunków, tematów i jednostek, w których miała być przeprowadzona kontrola. Piotr Jaroszewicz nie mógł [też - przyp. KL] pogodzić się z tym, że zgodnie z konstytucją - NIK każdego roku przedkładała Sejmowi uwagi do sprawozdania rządu z wykonania planu i budżetu. W uwagach tych, obok osiągnięć rządu wykazywano wszelkie niedomagania, słabości i błędy w działalności rządu. Formułowano oceny rzeczywistego stanu gospodarki. Na podstawie takiej oceny NIK zgłaszała wniosek o udzielenie absolutorium rządowi za miniony rok. Fakt ten bardzo bulwersował premiera. Jego zdaniem obowiązek ten należało nałożyć wyłącznie na Sejmową Komisję Planu Gospodarczego Budżetu i Finansów ${ }^{36}$. Aby cel ten osiągnąć, musiał doprowadzić do zmiany odpowiednich przepisów w konstytucji i ustawie o NIK. Na drodze zmiany podporządkowania, cele te w pełni osiągnął. [... $]^{37}$

Zapewne na długo pozostanie dla mnie zagadką: co faktycznie legło u podstaw nie najlepszych stosunków pomiędzy Mieczysławem Moczarem, a Piotrem Jaroszewiczem, czy też Wojciechem Jaruzelskim ${ }^{38}$ lub Stanisławem

${ }^{34}$ Dziennik Ustaw (dalej: Dz.U.) 1976, nr 12, poz. 66.

${ }^{35}$ Dyskusyjna teza: w 1976 r. ukarano 313 osób na kwotę 1,2 mln zł, w 1979 były to 772 osoby na kwotę 3,2 mln zł, a w 1980 r. 807 osób na kwotę 3,4 mln zł; zob. K. Lesiakowski, Professional negligence, mismanagement and malpractice Polish companies in the light of Supreme Audit Office materials in the years 1976-1980, „Studia Historiae Oeconomicae” 2016, vol. 34, s. 16; Archiwum Akt Nowych (dalej: AAN), PZPR, 4014, Sprawozdanie z działalności Najwyższej Izby Kontroli w 1981 r., Warszawa 1981 r., k. 9.

${ }^{36}$ Dotąd Komisja ta składała sprawozdanie $\mathrm{z}$ wykonania przez rząd narodowego planu gospodarczego i budżetu państwa wraz z wnioskiem NIK w przedmiocie absolutorium; zob. AAN, PZPR, 1758, Protokół posiedzenia Biura Politycznego KC, Warszawa, 20 VI 1972 r., k. 484-485.

${ }^{37}$ Pominięto fragment traktujący o niezadowoleniu pracowników NIK z przeprowadzonych zmian $\mathrm{w}$ formalnym usytuowaniu Izby w systemie organizacyjnym państwa.

${ }^{38}$ Wojciech Jaruzelski (1923-2014) - zawodowy wojskowy i polityk komunistyczny. W czasie II wojny światowej wywieziony w głąb Związku Socjalistycznych Republik Radzieckich (ZSRR), od 1943 r. w WP, po wojnie robił błyskotliwą karierę w armii: 1960-1965 szef Głównego Zarządu Politycznego, szef Sztabu Generalnego 1965-1968, wiceminister 1962-1968 i minister obrony 
Kanią ${ }^{39}$ ? Wprawdzie Piotr Jaroszewicz w swojej książce Przerywam milczenie ${ }^{40}$ usiłuje za to obciążyć Moczara, ale zawarte tam „zarzuty” są zdecydowanie nieprawdziwe. $\mathrm{N}$ [a] p[rzykład] zarzut, że Moczar nie przekazywał informacji z przeprowadzonych kontroli. Przeczą temu dokumenty znajdujące się w archiwach NIK. Nie będę mówił o innych „zarzutach”, których prawdziwość budzi we mnie głęboką wątpliwość, a nawet uczucie zażenowania. Oświadczam z całą stanowczością, że nie otrzymałem od prezesa Moczara ani jednej informacji, którą przechowywałby w swoim sejfie i dopiero w 1980 r. wykorzystał ją przeciwko komukolwiek. [...] ${ }^{41}$

$Z$ reguły od wszystkich adresatów (wyjąwszy I sekretarza [KC] PZPR) otrzymywaliśmy pisma aprobujące nasze zamierzenia kontrolne. Zdarzało się, że otrzymywaliśmy uwagi i wnioski do planu kontroli, zwłaszcza od Prezydium Sejmu, Przewodniczącego Rady Państwa, wiceprezesów Rady Ministrów. Często od sekretarzy KC PZPR zajmujących się problematyką ekonomiczną i rolną. Wnioski te $\mathrm{z}$ reguły uwzględnialiśmy w naszych planach kontroli. Oczywiście były przypadki zgłaszania tematów, które w niezbyt odległej przeszłości były przedmiotem kontroli lub też przewidziane były w najbliższej przyszłości do tzw. kontroli sprawdzających. W takich przypadkach, po uprzedniej rozmowie z osobą zainteresowaną, podejmowano decyzję ostateczną.

W archiwach Izby znajduje się wiele pism, w których Marszałek Sejmu, Przewodniczący Rady Państwa i Prezes Rady Ministrów serdecznie dziękują Mieczysławowi Moczarowi za interesujące, wnikliwe i bardzo przydatne materiały i opracowania z przeprowadzonych przez NIK kontroli. Do tych pism Moczar odnosił się z dużą uwagą, chociaż bardzo często podkreślał, że wolałby otrzymać chociaż jedno pismo, w którym zawarta byłaby rzeczowa krytyka i uwagi merytoryczne dotyczące naszej pracy. $Z$ dużą rezerwą odnosił się do tego rodzaju pism przychodzących od poszczególnych ministrów. W przypływie dobrego humoru

narodowej 1962-1983, premier 1981-1985, przewodniczący Wojskowej Rady Ocalenia Narodowego 1981-1983, I sekretarz KC PZPR 1985-1989, przewodniczący Rady Państwa 1985-1989, prezydent PRL i Rzeczpospolitej Polskiej 1989-1990. Poseł na Sejm 1961-1989. Według danych z archiwum Instytutu Pamięci Narodowej (IPN) w latach 1946-1954 współpracował w Informacją Wojskową ps. „Wolski”. T. Mołdawa, op. cit., s. 364; P. Piotrowski, Sprawa współpracy Wojciecha Jaruzelskiego z Informacja Wojskowa. Rekonesans archiwalny, „Biuletyn IPN” 2007, nr 1-2, s. 116-125.

39 Stanisław Kania (1927-2020) - polityk komunistyczny. Pracownik aparatu ZG ZMP 1952-1956, kierownik Wydziału Rolnego KC PZPR 1958-1962, kierownik Wydziału Administracyjnego KC 1968-1971, sekretarz KC 1971-1980, członek Biura Politycznego KC 1975-1981, I sekretarz KC PZPR 1980-1981, członek Rady Państwa 1982-1985. Poseł na Sejm 1972-1989. T. Mołdawa, op. cit., s. 369.

${ }^{40}$ P. Jaroszewicz, B. Roliński, Przerywam milczenie, Warszawa 1991.

${ }^{41}$ Pominięto dalszy ciąg myśli Piłatowskiego w sprawie konsekwentnego informowania przez NIK Sejmu i innych organów państwa o wynikach kontroli. 
mówił: „nikt, łącznie ze mną nie lubi kontroli [ale] nie chodzi o to, aby nas lubiano, chodzi o to, aby nas poważano i szanowano". A kiedy aparat nasz może cieszyć się szacunkiem i poważaniem? I odpowiadał: ,jedynie wówczas, gdy nasze kontrole będą obiektywne, wnikliwe, a ustalenia kontrolne będą niepodważalne".

Jak z powyższego wynika, od strony oficjalnej w stosunkach $\mathrm{z}$ najwyższymi czynnikami w państwie „wszystko było w porządku”. W praktyce jednak wyczuwało się sporą dozę rezerwy, a nawet elementy nieufności. A oto kilka przykładów: Edward Gierek przez szereg lat nie mógł znaleźć czasu, aby przyjąć na rozmowę prezesa NIK. Natomiast na kilku naradach kierowniczej kadry partyjnej i państwowej krytycznie wypowiadał się o pracy NIK. Bynajmniej nie chodziło o rzeczową krytykę poszczególnych kontroli. Chodziło o ogólniki typu: „NIK popada w czarnowidztwo! Nie potrafi dostrzec ogromnego dorobku w unowocześnianiu naszej gospodarki [i] umacnianiu jedności moralno-politycznej naszego społeczeństwa po 1970 r.!" Po przedstawieniu władzom centralnym materiałów krytycznych z kontroli dotyczącej niekorzystnych dla strony polskiej kontraktów zawartych przez nasz rząd $\mathrm{z}$ jedną $\mathrm{z}$ firm amerykańskich na dostawę kompletnych urządzeń dla zakładów mięsnych, chłodni, zamrażalni, itp. ${ }^{42}[-]$ niekorzystnych, bo droższych i mniej nowoczesnych, [od] oferowanych Polsce m.in. przez firmy niemieckie i austriackie, rozpętała się burza. Na kolejnej naradzie w KC partii ówczesny członek Biura Politycznego i Minister Rolnictwa i Przemysłu Spożywczego - Kazimierz Barcikowski ${ }^{43}$ - pomijając merytoryczną treść ustaleń kontroli stwierdził, że „NIK pracuje w oderwaniu od rzeczywistości. Eksperci NIK planują rozwój przemysłu spożywczego pod przednówek, a nie pod żniwa”. Edward Gierek jeszcze bardziej zaostrzył tę krytykę stwierdzając, że „kierownictwo partii i rządu nie pozwoli na to, aby NIK rzucała kłody pod nogi, aby przeszkadzała w szybkim uprzemysłowieniu i unowocześnieniu materialno-technicznej bazy socjalizmu". Bardzo charakterystycznym było to, że im bardziej nasilały się te nieprzychylne

\footnotetext{
${ }^{42}$ Trudno powiedzieć, o jakiej kontroli w tym miejscu wspomina Piłatowski. W sprawozdaniach z działalności NIK pojawiają się np. takie kontrole jak: Skutki zmian organizacyjnych w przemyśle mięsnym (1972), Zagospodarowanie surowców mięsnych oraz jakość i nowoczesność wyrobów produkowanych w kluczowym przemyśle mięsnym (1973), Efektywność wykorzystania zasobów surowcowych w gospodarce mięsnej (1975), Rozwój i efektywność przemysłowego tuczu trzody chlewnej w kluczowym przemyśle mięsnym (1976); zob. Sprawozdanie z działalności Najwyższej Izby Kontroli w 1972 r., Warszawa 1973, s. 80; Sprawozdanie z działalności Najwyższej Izby Kontroli w 1973 r., Warszawa 1974, s. [76]; Sprawozdanie z działalności Najwyższej Izby Kontroli w 1975 r., Warszawa 1976, s. [41]; Sprawozdanie z działalności Najwyższej Izby Kontroli w 1976 r., Warszawa 1977, s. [44].

${ }^{43}$ Kazimierz Barcikowski (1927-2007) - polityk komunistyczny i działacz młodzieżowy, ekonomista. W latach 1956-1957 sekretarz ZG ZMP, następnie do 1960 r. wiceprzewodniczący ZG Związku Młodzieży Wiejskiej, I sekretarz KW w Poznaniu 1968-1970, sekretarz KC 19701974, minister rolnictwa i członek Prezydium Rządu 1974-1977, wicepremier w 1980, członek BP KC 1980-1989, zastępca przewodniczącego Rady Państwa 1985-1989. Poseł na Sejm 19651989. T. Mołdawa, op. cit., s. 333.
} 
wobec NIK opinie, tym większymi krokami zbliżał się kryzys 1976 r., jako zapowiedź głębszego i kolejnego przesilenia w 1980 r. Mieczysław Moczar wnikliwie obserwując to, co się wokół działo, coraz częściej podkreślał, że głęboki kryzys jest nieuchronny. Coraz głębiej niepokoiło go odrywanie się kierownictwa partyjnego od rzeczywistości, jego arogancja i kompletny brak pozytywnego programu, który stwarzałby nadzieję na wyjście z narastającego w szybkim tempie kryzysu.

W początkowej fazie wielkiego zrywu robotniczego dostrzegał życiodajną siłę zdolną do skutecznego przeciwstawienia się wszelkiemu złu, siłę, która pomoże partii w oczyszczeniu się z elementów karierowiczowskich i z ludzi o nieczystych rękach. Był zwolennikiem hasła „socjalizm - tak, wypaczenia - nie!”. W latach 1980-1981 przyjeżdżały do Mieczysława Moczara [tzn. do siedziby NIK - przyp. KL] dziesiątki delegacji dziennie z różnych regionów kraju. Najwięcej ze Śląska i Zagłębia, Rzeszowa, Kielc, Krakowa, Lublina i innych. Ludzie szukali u niego rady, chcieli poznać jego poglądy na temat zaistniałej sytuacji i nadchodzących nieuchronnie zmian. Nieraz do późnych godzin nocnych czekały w kolejce delegacje, aby się z nim spotkać. W wielu rozmowach uczestniczyłem osobiście. Byłem pod dużym wrażeniem trafności jego ocen. Jego umiejętność bezpośredniego, gawędziarskiego sposobu mówienia o sprawach dużych i ważnych. Cechowała go wielka cierpliwość w wyjaśnianiu zawiłości ówczesnej sytuacji, a jednocześnie żarliwa pryncypialność $\mathrm{w}$ obronie podstawowych wartości idei socjalizmu i ogromnych zdobyczy ekonomicznych i socjalnych. Ogromnego wprost awansu społecznego i kulturowego naszego społeczeństwa. Wnioski wynikające z odbytych rozmów, z ogromnej ilości listów i petycji, które do niego napływały z dnia na dzień, przekazywał kierownictwu partii i państwa.

W sytuacji krytycznej zdecydował się wystąpić z listem do członków KC PZPR, żądając podjęcia zdecydowanych rozwiązań polityczno-personalnych ${ }^{44}$. Był głęboko zaniepokojony defensywną postawą partii, wyczekującą i bezradną postawą jej Komitetu Centralnego. Był przekonany, że sytuacja taka coraz bardziej sprzyja wzrostowi sił ekstremalnych w łonie nowych związków zawodowych. Miał poważne obawy, że „Solidarność” może wymknąć się spod kontroli [Lecha] Wałęsy ${ }^{45}$ i wówczas dojdzie do rozlewu krwi i koniecznoś[ci] użycia wojska lub,

${ }^{44}$ Chodzi o list Moczara do Biura Politycznego KC PZPR z 2 września 1980 r., zaczynający się od słów: „Szanowni Towarzysze!” (Kopia listu w posiadaniu autora). W liście tym znalazły się ogólne słowa o potrzebie zajęcia przez KC „zasadniczego stanowiska w sprawie powołania nowego kierownictwa” oraz statutowej reorganizacji tego kierownictwa w takim duchu aby wykluczyć „nadmierną koncentrację władzy w Partii w rękach jednej osoby".

${ }^{45}$ Lech Wałęsa (ur. 1943) - robotnik, opozycjonista, działacz Niezależnego Samorządnego Związku Zawodowego (NSZZ) „Solidarność”. Od 1967 r. pracownik fizyczny Stoczni im. Lenina w Gdańsku, uczestnik rewolty robotniczej z 1970 r., działacz Wolnych Związków Zawodowych, lider strajku w sierpniu 1980 r., od września 1980 r. współorganizator i przywódca „Solidarności” w Polsce, internowany 1981-1982, przewodniczący Krajowej Komisji Wykonawczej NSZZ „Solidarność” 1987-1990, współprzewodniczący obrad Okrągłego Stołu, prezydent RP 1990-1995. Laureat 
co najgorsze, interwencji zbrojnej ówczesnego Związku Radzieckiego i jego sojuszników. Bardzo obawiał się radzieckiej interwencji zbrojnej. Gdy na granicy wschodniej grupowano radzieckie dywizje, a do kraju napływała coraz większa liczba radzieckich generałów i oficerów sztabowych, pod pretekstem przygotowania warunków do przeprowadzenia międzysojuszniczych manewrów, Moczar kreślił ponury obraz naszej przyszłości. Z jednej strony, w obliczu radzieckiej interwencji zbrojnej, często powtarzał: „Polska to nie Czechosłowacja... ${ }^{46 ”} \mathrm{Z}$ drugiej strony, [w związku z] narastani[em] agresywnych tendencji w kierownictwie „Solidarności”, wyrazem czego była narada w Radomiu ${ }^{47}$ i zapowiedź przejścia do rozwiązań siłowych - gen. Moczar zaostrzył swój krytyczny punkt widzenia co do możliwości pokojowego wyjścia z kryzysu. Przypuszczam, że dlatego ze zrozumieniem przyjął wprowadzenie stanu wojennego. Widział w tym skuteczną tarczę ochronną przed interwencją zbrojną ZSRR i państw Układu Warszawskiego.

Pamiętam, że w niedzielę wieczorem, w dniu 13 grudnia 1981 r., byłem w gabinecie u prezesa, rozmawialiśmy na temat aktualnej sytuacji. Odczułem, iż jest wyraźnie zadowolony z tego, że w pierwszym dniu udało się uniknąć strat ludzkich. „Jeżeli dalej sytuacja będzie się rozwijać w ten sposób, to ułatwi to znakomicie podjęcie rozmów $\mathrm{z}$ opozycją w najbliższym czasie" - powiedział. W tym momencie zadzwonił telefon rządowy. Po chwili prezes odłożył słuchawkę i powiedział zwracając się do mnie: "W drodze jest [Michał] Atłas ${ }^{48}$ (kierownik Wydziału Administracyjnego KC), jedzie do mnie w bardzo ważnej sprawie". Wobec tego podniosłem się i zamierzałem wyjść. Prezes ruchem ręki wskazał mi fotel. „Siadaj, zaraz zamówię kawę" - powiedział. Po kilku minutach do gabinetu wszedł Atłas. Sekretarka podała kawę. Atłas wyjął z teczki plik papierów i powiedział: „Towarzyszu prezesie, z polecenia sekretarza partii, Mirosława Milewskiego ${ }^{49}$,

Pokojowej Nagrody Nobla (1983). Wg danych z archiwum IPN w latach 1970-1976 zarejestrowany jako współpracownik Służby Bezpieczeństwa ps. „Bolek”; S. Cenckiewicz, P. Gontarczyk, SB a Lech Watęsa. Przyczynek do biografii, Gdańsk-Warszawa-Kraków 2008, s. 295-338, passim.

${ }^{46}$ Chodzi o interwencję zbrojną pięciu państw Układu Warszawskiego w Czechosłowacji w sierpniu 1968 r., która stłumiła wolnościowe dążenia Czechów i Słowaków.

${ }^{47}$ Nieformalne posiedzenie Prezydium Komisji Krajowej i przewodniczących zarządów regionalnych NSZZ „Solidarność” w Radomiu 3 grudnia 1981 r. W jego trakcie przedstawiono radykalne pomysły na przeciwstawienie się władzy, która przygotowywała się do uchwalenia ustawy o nadzwyczajnych pełnomocnictwach dla rządu. Odpowiednio spreparowane nagrania zostały wykorzystane przez reżim do propagandowego uzasadnienia wprowadzenia stanu wojennego. Szerzej zob. A. Friszke, Rewolucja Solidarności 1980-1981, Kraków 2014, s. 895-899.

${ }^{48}$ Michał Atłas (ur. 1923) - pracownik aparatu PZPR. W latach 1958-1960 I sekretarz Komitetu Powiatowego PZPR w Szczytnie, następnie sekretarz KW w Olsztynie 1960-1972, później inspektor w KC, 1977-1980 zastępca kierownika Wydziału Prasy, Radia i Telewizji, a w latach 19801984 kierownik Wydziału Administracyjnego KC. https://katalog.bip.ipn.gov.pl/informacje/1333 (dostęp: 25 III 2020).

${ }^{49}$ Mirosław Milewski (1928-2008) - wysoki funkcjonariusz aparatu bezpieczeństwa, polityk komunistyczny, z wykształcenia inżynier rolnik. Od 1944 r. w aparacie bezpieczeństwa, 1969-1971 
przedkładam wam listę osób internowanych do wiadomości i akceptacji ${ }^{50}$. Proszę o wasz podpis”. Moczar zapytał: „powiedz mi Atłas - kto i kiedy opracował tę listę?" Atłas odpowiedział, że nic w tej sprawie nie może odpowiedzieć, bo po prostu nie wie. Po chwili Moczar odpowiedział: „Nie mogę podpisać tych list, ponieważ na ich opracowanie nie miałem żadnego wpływu. A poza tym ludzie, których nazwiska są na tych listach, znajdują się już w miejscach odosobnienia. Nie wiem nawet gdzie i w jakich warunkach oni się znajdują. Wiadomo mi, że wśród internowanych znaleźli się bardzo porządni ludzie. Są też wśród nich moi przyjaciele ${ }^{51}$. Wśród internowanych znalazła się też grupa posłów na $\mathrm{Sejm}^{52}$, dopuszczono do nieuzasadnionego naruszenia immunitetu poselskiego. Moczar wziął do ręki przyniesiony przez Atłasa plik papierów i zaczął głośno odczytywać nazwiska osób internowanych. Po odczytaniu wszystkich nazwisk oddał Atłasowi te papiery z takim komentarzem: „Bardzo pobieżny wgląd do listy nakazuje mi wyrazić pogląd, że co najmniej $70 \%$ osób należałoby natychmiast przeprosić, zwolnić i odesłać do domów na koszt państwa". Po tym nastąpiła dłuższa chwila ciszy. Zrobiło się nam bardzo smutno. Na usta cisnęło się pytanie: jak mogło do tego dojść? Pytanie, na które odpowiedź jeszcze dziś nie jest w pełni możliwa. Postawa generała Mieczysława Moczara w tamtej sytuacji była ewenementem. $[\ldots]^{53}$

Sądzę, że te cechy charakteru nie przysporzyły Moczarowi przyjaciół wśród osób najwyżej postawionych w hierarchii partyjnej i państwowej. Moczar swoją osobowością, sposobem bycia wzbudzał respekt nie tylko u podwładnych, ale i wśród wyżej postawionych. Bardzo często zastanawiałem się nad tym, czy tylko

dyrektor Departamentu I w Ministerstwie Spraw Wewnętrznych (MSW), wiceminister spraw wewnętrznych 1971-1980, a następnie minister 1980-1981, sekretarz KC 1981-1985.

${ }^{50} \mathrm{Nic}$ nie wskazuje na to, żeby ekipa gen. Wojciecha Jaruzelskiego konsultowała z czynnikami krajowymi listę internowanych. Otwarte pozostaje pytanie, czy prezes NIK nie otrzymał tego wykazu (może tylko cząstkowego, np. obejmującego ludzi z kręgu władzy) post factum i wyłącznie do wiadomości? Nie zachodziła wtedy potrzeba składania podpisu, chyba że rozumianego jako potwierdzenie zapoznania się z tym dokumentem.

${ }^{51}$ Do grona osób bliskich Moczarowi, przynajmniej w przeszłości, można zaliczyć chyba tylko internowanego Józefa Majchrzaka, byłego I sekretarza KW PZPR w Bydgoszczy, wtedy posła z ziemi bydgoskiej (mandat poselski sprawował w latach 1965-1981).

52 Posłami na Sejm VIII kadencji (1980-1985) było co najmniej dziewięciu internowanych, umieszczonych w specjalnym ośrodku dla byłych ludzi władzy w Głębokiem koło Drawska Pomorskiego. Byli to m.in. Edward Gierek (były I sekretarz KC PZPR), Zdzisław Grudzień (były I sekretarz KW PZPR w Katowicach), Piotr Jaroszewicz (były premier), Tadeusz Pyka (były wicepremier), Jan Szydlak (były wicepremier), Tadeusz Wrzaszczyk (były wicepremier). Należy jednak zauważyć, że w chwili wprowadzenia stanu wojennego wymienione osoby formalnie nie posiadały już mandatów poselskich - zrzekli się ich w grudniu 1980 r. lub lipcu 1981 r. M. Maciejowski, Partyjni dygnitarze w odosobnieniu, „Pamięc.pl” 2012, nr 9, s. 55; http://orka.sejm.gov.pl/ArchAll2. nsf (dostęp: 1 IV 2020).

${ }^{53}$ Pominięto fragment na temat charakteru Moczara. 
respekt. A może i obawy? Myśl ta głęboko mnie niepokoi, zwłaszcza po przeczytaniu książki Piotra Jaroszewicza Przerywam milczenie. Autor sugeruje, że nawet premier rządu ZSRR - Aleksiej Kosygin ${ }^{54}$ obawiał się rozmawiać z nim w gmachu R[ady] W[zajemnej] P[omocy] G[ospodarczej] w Moskwie, bo i tam wszechwładny Moczar miał zainstalować aparaturę podsłuchową. Groteskowe i żenujące są te zwierzenia autora! Podobnie nie mogę znaleźć racjonalnego uzasadnienia przyczyn dużej zmienności stosunku - od demonstrowanej, serdecznej przyjaźni do Moczara, po przenikający chłód i całkowite dystansowanie się od niego takich osób jak: Wojciech Jaruzelski, Stanisław Kania, czy Edward Babiuch. Ta „miłość bez wzajemności” była i pozostaje dla mnie niezrozumiała. Tym bardziej, że Moczar był wobec tych ludzi lojalny. Nie tolerował tego, aby w jego obecności ktokolwiek wyrażał się o nich lekceważąco. W takich przypadkach stanowczo „ucinał” wszelkie dywagacje na ich temat. Szczególnie wrażliwy był, gdy dotyczyło to Wojciecha Jaruzelskiego i Stanisława Kani. Moczar wierzył tym ludziom, dlatego zawód, który go spotkał z ich strony, przeżył bardzo dotkliwie.

Rok 1980 charakteryzował szybki wzrost napięć społecznych. Strajki, demonstracje dezorganizowały produkcję, ograniczały niemal do zera zapasy materiałowo-towarowe w magazynach. Pogarszało się z dnia na dzień zaopatrzenie rynku, powodując uzasadniony wzrost niezadowolenia społeczeństwa i krytyki w stosunku do partii i władzy. W nocy z 5 na 6 września 1980 r. zebrało się VI Plenum KC PZPR. Dokonało ono zmian na stanowisku I sekretarza - stanowisko to po Edwardzie Gierku objął Stanisław Kania. Na tym obrady plenum przerwano i wznowiono je dopiero 4 i 5 października. Dokonano pewnych zmian w składzie kierownictwa, do Biura Politycznego wybrano ponownie Mieczysława Moczara ${ }^{55}$. $\mathrm{Na}$ zakończenie obrad plenum podjęło uchwałę, w której m.in. zobowiązało NIK do podjęcia działań kontrolno-wyjaśniających $\mathrm{w}$ stosunku do prywatnego budownictwa mieszkaniowego i rekreacyjnego we wszystkich przypadkach, w których opinia publiczna podnosi[ła] zastrzeżenia dotyczące nieprawidłowości lub nadużyć popełnionych przez ich właścicieli56. NIK miała też zapewnić bieżącą informację o postępie i wynikach swej pracy, zarówno instancjom partyjnym, jak i opinii

\footnotetext{
${ }^{54}$ Aleksiej Kosygin (1904-1980) - polityk sowiecki. Od 1942 r. w oblężonym przez Niemców Leningradzie, jako pełnomocnik Komitetu Obrony Państwa, premier Rosyjskiej Federacyjnej Republiki sowieckiej 1943-1946, członek Biura Politycznego KC komunistycznej partii w ZSRR od 1946 r., I wicepremier 1960-1964, premier Związku Radzieckiego 1964-1980. Komisja Tadeusza Grabskiego (1981), oprac. M. Jabłonowski, W. Janowski, Warszawa 2013, s. 658.

${ }^{55}$ Członkiem Biura Politycznego Moczar został dwa miesiące później. Wybrało go na to stanowisko VII Plenum KC PZPR, obradujące w dniach 1-2 grudnia 1980 r.; zob. PZPR a Solidarność 1980-1981. Tajne dokumenty Biura Politycznego, wstęp T. Kozłowski, Warszawa 2013, s. 861.

56 „7. Zgodnie z obowiązującym prawem NIK i organa finansowe sprawdzą z punktu widzenia źródeł pokrycia, wszystkie budzące wątpliwości prywatne inwestycje budowalne zrealizowane $\mathrm{w}$ ostatnim dziesięcioleciu, $\mathrm{w}$ tym również domy letniskowe oraz zbudowane poza gospodarstwami rolniczymi domy jednorodzinne”, zob. Uchwała, „Trybuna Robotnicza”, 7 X 1980 r., s. 3.
} 
publicznej. Formalnie rzecz biorąc, cel wynikający z treści uchwały Plenum KC był szlachetny. Opinia publiczna dowiedziała się, że oto PZPR i rząd chcą, aby wszyscy ci, którzy kosztem społeczeństwa usiłowali się wzbogacić, zostali zgodnie z prawem pociągnięci do odpowiedzialności. Na różnych zebraniach i naradach, pod wpływem ostrej krytyki, zarówno Stanisław Kania, jak i Wojciech Jaruzelski, składali oświadczenia, że to Najwyższą Izbę Kontroli zaangażowano do przeprowadzenia kontroli. Podkreślano, że kontrola ma charakter powszechny, to znaczy, że nikt, w stosunku do kogo zostały lub zostaną wysunięte zarzuty o popełnieniu nadużyć lub naruszeniu norm współżycia społecznego, niezależnie od zajmowanego stanowiska, nie może być wolny od kontroli. „Macie, tak jak i my mamy, zaufanie do NIK, bądźcie zatem cierpliwi, wszystkie sprawy będą wyjaśnione do końca, a winni zostaną pociągnięci do odpowiedzialności”. W taki sam sposób rozumiał to zagadnienie Mieczysław Moczar ${ }^{57}$. Z całą powagą odnosząc się do Uchwały Plenum KC, uważał za swój obowiązek, aby instytucja, którą kierował, wniosła maksymalny wkład pracy w udzielenie partii i rządowi pomocy w usunięciu nagromadzonego zła.

$\mathrm{Na}$ drugi dzień po zakończeniu obrad Plenum KC prezes zebrał całe kierownictwo Izby dla omówienia zadań, które aparat kontrolerski musi podjąć w związku z Uchwałą $\mathrm{KC}^{58}$. Ustalił, że wiceprezesi nadzorujący podległe im jednostki administracyjne (zespoły, departamenty, delegatury) będą osobiście odpowiedzialni za prawidłową realizację w/w uchwały. Całokształt zagadnień koordynacyjnych $\mathrm{w}$ tej dziedzinie oraz reprezentowanie $\mathrm{w}$ tych sprawach na zewnątrz zostało powierzone mnie. Do moich obowiązków należało też bieżące informowanie prezesa i kolegium NIK o przebiegu realizacji ustalonych zadań. W oparciu o odpowiednie zarządzenie prezesa NIK, powołany został Centralny Zespół Koordynacyjny [CZK]. W jego składzie znaleźli się m.in. przedstawiciel CKKP, Komendy Głównej M[ilicji] O[bywatelskiej], Inspektoratu Kontrolno-Rewizyjnego i inni. Na pierwszym posiedzeniu CZK omówił i zaakceptował szczegółowy plan działań NIK oraz innych organów kontroli, inspekcji i lustracji, które zadeklarowały swój udział w realizacji uchwał VI Plenum KC. Członków zespołu zapoznano z treścią informacji, które w liczbie 10 tys. szt[uk] napłynęły do NIK i dotyczyły blisko 11 tys. osób. Podjęta została decyzja, aby całą

${ }^{57} \mathrm{O}$ wzrastającej liczbie „różnego typu informacji napływających od obywateli, dotyczących wszelkiego typu zauważonych nieprawidłowości życia społecznego" mówiono podczas posiedzenia Kolegium NIK, z udziałem Piłatowskiego, 24 września 1980 r. Dzień wcześniej centralę Izby miała odwiedzić delegacja górników, reprezentująca 40 tys. pracowników tej branży, z żądaniem "natychmiastowego podjęcia badań kontrolnych, wskazanych przez nich spraw”. Zob. ANIK, DP, 126/1, Protokół nr 24/80, Warszawa, 24 IX 1980 r., k. 152-153.

${ }^{58}$ Podczas posiedzenia Kolegium NIK w październiku 1980 r. prezes Izby zachęcał poległy aparat do intensywnej pracy, traktowanej jako „pomoc dla Partii w rozwiązywaniu istniejących problemów, przeprowadzając wnikliwą analizę i działając z prowokacyjną śmiałością", zob. ANIK, DP, 121/1, Protokół nr 26/80, Warszawa, 22 X 1980 r., k. 166. 
korespondencję poddać wnikliwej analizie w celu wyeliminowania tych informacji, które charakteryzowała nienawiść polityczna, narodowościowa lub chęć zemsty bądź dążenie do skompromitowania osób, zwłaszcza na stanowiskach kierowniczych. Po przeprowadzeniu wnikliwej oceny każdej informacji przez powołanych specjalnie do tej pracy emerytów, byłych pracowników NIK, wytypowano do badań kontrolnych 4500 szt[uk] informacji, które dotyczyły 6500 osób, w tym 3628 osób zajmujących różne kierownicze stanowiska. I w ten sposób NIK ze szkodą dla swych ustawowych obowiązków rzucona została przez kierownictwo partii w otchłań wielomiesięcznej, niezwykle pracochłonnej działalności kontrolnej, prowadzonej w bardzo niesprzyjających warunkach. Wymienię tylko niektóre z nich:

- NIK nie posiadała odpowiednich przepisów prawnych, które pozwalały na prowadzenie postępowania kontrolno-wyjaśniającego w stosunku do osób (patrz ustaw[y] o NIK z 1976 r. i 1980 r. ${ }^{59}$ ).

- Kontrole prowadzone były w warunkach społecznego niezadowolenia, masowych strajków, okupowania pomieszczeń dyrekcji, organów władzy terenowej, itp.

- Kontrolerzy działali pod dużym naciskiem środowisk społecznych, które domagały się szybkiego prowadzenia kontroli i natychmiastowego, publicznego ujawniania winnych.

- Począwszy od wiosny 1981 r. różne prominentne osoby, będąc pod silnym naporem opinii publicznej, krytykowały NIK za nadmierną przewlekłość i niedostateczne informowanie opinii społecznej o ich wynikach. Coraz wyraźniej dało się zaobserwować, że ówczesne kierownictwo partii i państwa, swoją postawą i wystąpieniami publicznymi usiłuje odwrócić od siebie ogromne niezadowolenie społeczeństwa i skierować je przeciwko NIK, że to ona jest odpowiedzialna za ujawnienie wszelkiego zła oraz osób za to odpowiedzialnych, oczywiście z wyłączeniem osób, które znajdowały się wówczas na szczytach władzy. Pomimo ogromnych trudności, zwłaszcza spowodowanych brakiem odpowiednich przepisów prawnych, co zmuszało NIK do działania poprzez inne, uprawnione do tego organa kontroli i ścigania, „akcja rozliczeniowa” w 97\% została zrealizowana przed rozpoczęciem obrad przez IX Nadzwyczajny Zjazd PZPR ${ }^{60}$. Jej wyniki opracowano w sprawozdaniu, które miało być przedmiotem oceny na posiedzeniu Biura Politycznego. Niestety, nigdy do tego nie doszło. Sądzę, że jest to jeszcze jeden z przykładów potwierdzających moje przypuszczenia o całkowitym dystansowaniu się najwyższych władz politycznych i państwowych do tej sprawy.

Ostateczny bilans działań kontrolno-wyjaśniających NIK i współdziałających z nią innych organów kontroli przedstawił się następująco:

\footnotetext{
${ }^{59}$ Chodzi o ustawę uchwaloną 8 października 1980 r., która ponownie podporządkowywała Izbę Sejmowi; zob. Dz.U. 1980, nr 22, poz. 80.

${ }^{60}$ Zjazd obradował w dniach 14-21 lipca $1981 \mathrm{r}$.
} 
- W stosunku do 3226 osób podniesione zarzuty zostały potwierdzone.

- W powyższej liczbie mieści się 2245 osób, które zajmowały różne stanowiska kierownicze.

- NIK wystąpiła do jednostek nadrzędnych z wnioskami obligatoryjnymi o zastosowanie sankcji służbowych w stosunku do 2286 osób, w tym do 599 osób wystąpiliśmy o odwołanie ze stanowisk kierowniczych.

- Do komisji kontroli partyjnej skierowaliśmy zawiadomienia o naruszeniu norm prawa i zasad współżycia społecznego w stosunku do 1327 członków PZPR.

- Do organów prokuratury skierowaliśmy wnioski o wszczęcie postępowań przygotowawczych w stosunku do 1188 osób.

- Niezależnie od powyższego, NIK wystąpiła do jednostek nadrzędnych z wnioskiem o wystąpienie przez nie na drogę cywilno-prawną, o zwrócenie nienależnych korzyści lub niezapłaconych kwot w stosunku do 2077 osób. W wyniku tych wystąpień wyrównało szkody lub zapłaciło należności dobrowolnie 1041 osób.

- W wyniku przeprowadzonej kontroli przez NIK i pod jej nadzorem 3240 osób, w tym 1379 osób zajmujących kierownicze stanowiska oczyszczonych zostało z ciążących na nich zarzutów. Wysunięte wobec tych osób zarzuty były całkowicie bezpodstawne, wynikały często $\mathrm{z}$ pobudek osobistych lub też z przyczyn politycznych. Ludzie ci byli głęboko wdzięczni za to, że NIK przywróciła im dobre imię w środowisku. Każda osoba, która oczyszczona została z ciążących na niej zarzutów, mogła otrzymać od NIK odpowiednie zaświadczenie w tej sprawie.

Do [podanej w ostatnim punkcie - przyp. KL] liczby 3240 osób, należałoby dodać co najmniej półtorej setki ludzi, którzy znaleźli się pod pręgierzem nieuzasadnionych zarzutów. Z własnej woli zwrócili się do NIK o przeprowadzenie postępowań wyjaśniających i wydanie im odpowiednich zaświadczeń. Wśród tej grupy ludzi znaleźli się: byli wicepremierzy - Zbigniew Szałajda ${ }^{61}$, Aleksander Kopeć $^{62}$, były ambasador w Moskwie Kazimierz Olszewski ${ }^{63}$, były I sekretarz

${ }^{61}$ Zbigniew Szałajda (ur. 1934) - polityk komunistyczny, inżynier mechanik. Przez lata związany z polskim hutnictwem - dyrektor naczelny Huty Kościuszko w Chorzowie 1970-1974, Huty Katowice w Dąbrowie Górniczej 1974-1980, minister hutnictwa / hutnictwa i przemysłu maszynowego 1980-1982, wicepremier 1982-1988, zastępca, później członek KC 1980-1990. T. Mołdawa, op. cit., s. 428.

${ }^{62}$ Aleksander Kopeć (1932-2015) - polityk komunistyczny, dr nauk ekonomicznych, inżynier mechanik. Przez lata związany z przemysłem - główny inżynier i dyrektor Fabryki Wagonów w Świdnicy 1962-1967, dyrektor Dolnośląskich Zakładów Wytwórczych Maszyn Elektrycznych Dolmel we Wrocławiu 1967-1970, minister przemysłu maszynowego 1975-1980, wicepremier 1980-1981. Prezes Naczelnej Organizacji Technicznej 1976-1984. Ibidem, s. 376.

${ }^{63}$ Kazimierz Olszewski (1917-2014) - polityk komunistyczny, urzędnik, dyplomata. W Armii Czerwonej 1943-1944, następniew WP, od 1947 r. w przemyśle - przedstawiciel PRL wRWPG w Moskwie 1959-1962, minister handlu zagranicznego 1971-1972, wicepremier 1972-1977 oraz minister żeglugi, następnie handlu zagranicznego i gospodarki morskiej 1973-1974, stały przedstawiciel PRL w RWPG 1975-1977, ambasador PRL w ZSRR 1978-1982, członek KC 1971-1981. Poseł na Sejm 1976-1980. W 1981 r. odsunięty na boczny tor, trafił do służby dyplomatycznej. Ibidem, s. 407. 
KW PZPR w Krośnie i Przemyślu, kilku ówczesnych wojewodów, dyrektorów, itp. Okazało się, że wszystkie osoby, które z własnej woli zwróciły się do NIK o przeprowadzenie w stosunku do nich postępowań kontrolno-wyjaśniających, nie dopuściły się żadnych nadużyć ani też naruszeń zasad współżycia społecznego. Wydane przez NIK zaświadczenia, tzw. „glejty” były szanowane przez opinię środowiskową.

Wiosną 1981 r. [29-30 kwietnia - przyp. KL] odbyło się X Plenum KC partii. Plenum powołało specjalną komisję, której zadanie polegało na zbadaniu przyczyn kryzysu oraz określeni[u] odpowiedzialności poszczególnych członków kierownictwa politycznego i państwowego za zaistniałą sytuację ${ }^{64}$. Przewodniczącym Komisji został sekretarz KC PZPR Tadeusz Grabski ${ }^{65}$. Włączył on do pracy w komisji Generalnego Prokuratora Lucjana Czubińskiego ${ }^{66}$, zastępcę przewodniczącego CKKP Jerzego Urbańskiego ${ }^{67}$ oraz wiceprezesa NIK Władysława Piłatowskiego. Tak więc od pierwszego do ostatniego dnia posiedzenia komisji brałem udział w jej pracy. Obrady komisji odbywały się przeważnie raz w tygodniu ${ }^{68}$. Na każde posiedzenie, na określone godziny zapraszano poszczególnych członków kierownictwa politycznego i państwowego. Rozmowę z Edwardem Gierkiem i Piotrem Jaroszewiczem zaplanowano na zakończenie prac komisji.

Każde posiedzenie komisji miało następujący przebieg: na wstępie przewodniczący Tadeusz Grabski informował zaproszoną osobę o tym, jaki jest cel komisji. Następnie członkowie komisji zgłaszali pytania. Po udzieleniu odpowiedzi przez zainteresowanego, padało kardynalne pytanie ze strony Grabskiego: „Czy NIK

${ }^{64}$ Uchwała Komitetu Centralnego w sprawie powołania komisji dla oceny dotychczasowego przebiegu i przyśpieszenia prac w kwestii odpowiedzialności, „Trybuna Robotnicza”, 1-3 V 1981 r., s. 2.

65 Tadeusz Grabski (1929-1989) - polityk komunistyczny, dr nauk ekonomicznych. W latach 19511956 w WP, następnie w przemyśle terenowym, m.in. dyrektor Wojewódzkiego Zjednoczenia Przemysłu Terenowego w Poznaniu. Później przewodniczący Prezydium Wojewódzkiej Rady Narodowej w Poznaniu 1972-1973, wojewoda poznański 1973-1975, I sekretarz KW w Koninie 1975-1979, dyrektor naczelny Zakładów Systemów Automatyki „Mera” w Poznaniu 1979-1980, wicepremier sierpień - październik 1980, sekretarz KC 1980-1981. Poseł na Sejm 1976-1980. T. Mołdawa, op. cit., s. 356.

${ }^{66}$ Lucjan Czubiński (1930-2020) - polityk komunistyczny, zawodowy wojskowy, dr hab. nauk prawnych. Przez większość swojego życia związany z prokuraturą wojskową - naczelny prokurator wojkkowy i zastępca prokuratora generalnego PRL 1968-1972, w 1971 r. członek komisji powołanej dla wyjaśnienia tzw. wydarzeń grudniowych, prokurator generalny PRL 1972-1981, zastępca członka/członek KC 1975-1981, dyrektor generalny MSW 1981-1983, podsekretarz stanu w MSW 1983-1990, uczestnik obrad Okrągłego Stołu w 1989 r. Ibidem, s. 343.

${ }^{67}$ Jerzy Urbański (ur. 1928) - pracownik aparatu PZPR, robotnik, absolwent Centralnej Szkoły Komsomołu w Moskwie. W latach 1951-1956 w aparacie ZMP, następnie PZPR - I sekretarz Komitetu Miejskiego w Żyrardowie, wiceprzewodniczący Warszawskiej Wojewódzkiej Komisji Kontroli Partyjnej 1966-1971, I sekretarz Komitetu Zakładowego w NIK 1971-1980, wiceprzewodniczący i przewodniczący CKKP 1980-1986, członek Centralnej Komisji Kontrolno-Rewizyjnej. Ibidem, s. 435.

${ }^{68}$ Pierwsze posiedzenie Komisji odbyło się 11 V 1981 r.; zob. Komisja Tadeusza Grabskiego..., s. 44. 
posiada ustalenia kontrolne w stosunku do...?” i tu padało określone nazwisko. Jeżeli takowe były, zobowiązany byłem do ich zreferowania członkom komisji w obecności osoby zainteresowanej. Muszę przyznać, że była to wyjątkowo niewdzięczna rola „oskarżyciela”, którą miałem spełnić. I tak np.:

- Jan Szydlak (członek B[iura] P[olitycznego] i wicepremier) - ustalenia kontrolne wykazały nieprawidłowości w rozliczeniach za wybudowany dom dwurodzinny na działce „wygospodarowanej” z terenów Parku Kościuszki w Katowicach. Przedsiębiorstwo Budownictwa Przemysłowego w Katowicach wystawiło rachunek za roboty budowlano-montażowe na sumę 1403 tys. zł. Do czasu kontroli Jan Szydlak zapłacił 802 tys. zł. Resztę należności (601 tys. zł) pokryto z dotacji państwa na „uzbrojenie terenów pod budownictwo mieszkaniowe”. W 1979 r. Przedsiębiorstwo Budownictwa Przemysłu Węglowego przeprowadziło w domu Szydlaka roboty budowlano-remontowe, wystawiając rachunek na sumę 39,9 tys. zł. Przeprowadzona kontrola w tym przedsiębiorstwie ujawniła zaniżenie rachunku o 140 tys. zł. W wyniku kontroli NIK, Jan Szydlak uregulował w pełni swoje „zaległości”. Fakt ten potwierdzony został przez delegaturę NIK w Katowicach.

- Franciszek Kaim ${ }^{69}$ (były wicepremier) - korzystał z usług hutniczego Przedsiębiorstwa Remontowego przy budowie domu w Magdalence ${ }^{70}$. Kontrola w tym przedsiębiorstwie wykazała, że należność za wykonane roboty została zaniżona o 684 tys. zł. W wyniku kontroli Kaim wpłacił 300 tys. zł, a pozostałe 384 tys. zł przedsiębiorstwo rozłożyło na kilka lat.

- Józef Kępa ${ }^{71}$ (były minister) - nabył wraz z synem od państwa dom mieszkalny o pow[ierzchni] użytkowej $230 \mathrm{~m}^{2}$ przy ul. Racławickiej $116 \mathrm{w}$ W[arsza]wie. Z budynku tego, przed jego sprzedażą, wykwaterowano lokatorów, przydzielając im 8 mieszkań o łącznej powierzchni $406 \mathrm{~m}^{2}$. Przy wycenie domu nie uwzględniono kosztów w wys[okości] 4,7 mln zł za wykonany remont i modernizację budynku. W wyniku tego i zastosowania 60\% zniżki, nabywcy zapłacili za ten dom zaledwie 1012 tys. zł. Ponadto, do budynku tego doprowadzono na koszt

${ }^{69}$ Franciszek Kaim (1919-1996) - polityk komunistyczny, inżynier metalurg (1919-1996). W czasie II wojny światowej pracował na roli i w leśnictwie, po wojnie związany z hutnictwem - dyrektor Huty „Małapanew” w Ozimku 1951-1953, minister przemysłu ciężkiego 1967-1970, wicepremier 1970-1979, minister hutnictwa 1976-1980. Członek KC PZPR 1971-1981, w lipcu 1981 r. usunięty z PZPR, a po wprowadzeniu stanu wojennego internowany. Poseł na Sejm 1972-1980. T. Mołdawa, op. cit., s. 343.

${ }^{70}$ Najpewniej chodzi o wieś w podwarszawskiej gminie Lesznowola (obecnie powiat piaseczyński). $\mathrm{W}$ tej miejscowości swoje działki i domy miało wielu tzw. prominentów PRL. Znajdował się tu także ośrodek rządowy.

${ }^{71}$ Józef Kępa (1928-1998) - polityk komunistyczny. W aparacie ZG ZMP 1950-1954, a od 1958 r. w aparacie PZPR - I sekretarz Komitetu Warszawskiego 1967-1976, przewodniczący Obywatelskiego Komitetu Odbudowy Zamku Królewskiego w Warszawie od 1971 r., członek Biura Politycznego 1975-1980, wicepremier 1976-1979, 1979-1981 minister administracji, gospodarki terenowej i ochrony środowiska. Poseł na Sejm 1969-1980. T. Mołdawa, op. cit., s. 371. 
państwa sieć ciepłowniczą, kosztem 6808 tys. zł. Powyższe środki finansowe, jak i moce przerobowe, przeniesione zostały $\mathrm{z}$ robót prowadzonych planowo w sąsiedniej ulicy, wstrzymując ich kontynuację na blisko rok (działo się to w latach 1974-1977).

- Stanisław Kowalczyk ${ }^{72}$ (były minister spraw wewnętrznych) - na działce małżonków Zofii i Stanisława Kowalczyków w Magdalence został wybudowany dom mieszkalny przez U[rząd] R[ady] M[inistrów]. Formalnie dom ten nie został przekazany małżeństwu Kowalczyków. Nie figurował w ewidencji majątku URM ani też w ewidencji domów przekazanych do użytku. Podatek od nieruchomości opłacał [jednak] Stanisław Kowalczyk. Z zebranych w toku kontroli dokumentów wynika, że ogólny koszt budowy przekroczył $7 \mathrm{mln}$ zł. Ustalono również, że małżonkowie Kowalczykowie wpłacili do kasy URM na poczet kosztów nie istniejącego nigdzie w ewidencji domu 601963 zł. Wystąpiliśmy z wnioskiem, aby dom ten został przyjęty przez URM lub przez MSW, za zwrotem rzeczywistych kosztów budowy do kasy URM.

- Janusz Wieczorek ${ }^{73}$ (były szef URM):

- Dopuścił do nieuzasadnionego powiększenia funduszu dyspozycyjnego URM, z $15 \mathrm{mln}$ w 1979 r. do 52,5 mln [zł] w roku 1980, z czego wykorzystano 38,5 mln. - W 1980 r. pobrał do własnej dyspozycji z Biura Finansowego URM kwotę $10 \mathrm{mln}$ zł, przy czym nie złożył do tegoż biura żadnych rozliczeń.

- Przejął za pokwitowaniem z gabinetu wiceministra Handlu Wewnętrznego [i Usług - przyp. KL] obraz [Juliana] Fałata ${ }^{74}$, będący własnością Muzeum Narodowego w Warszawie. Kontrola nie potrafiła ustalić, gdzie obraz ten się znajduje.

${ }^{72}$ Stanisław Kowalczyk (1924-1998) - polityk komunistyczny, generał MO. Podczas okupacji pracował w przemyśle włókienniczym w Pabianicach, a po wojnie w przemyśle chemicznym, karierę polityczną zaczynał w Polskiej Partii Socjalistycznej (PPS), od 1950 r. w aparacie PZPR - kierownik Wydziału Przemysłu Ciężkiego i Komunikacji/Przemysłu i Komunikacji w KC 1968-1973, sekretarz KC 1971-1973, członek Biura Politycznego KC 1975-1980, minister spraw wewnętrznych 1973-1980, twórca Samodzielnej Grupy „D” (dezintegracja) w „antykościelnym” IV Departamencie MSW, wicepremier 1980-1981. Poseł na Sejm 1969-1982. T. Mołdawa, op. cit., s. 377; https://katalog.bip.ipn.gov.pl/informacje/1029?katalog=4 (dostęp: 25 III 2020).

${ }^{73}$ Janusz Wieczorek (1910-1981) - urzędnik państwowy wysokiej rangi, z wykształcenia prawnik. Przed wojną pracował jako księgowy i buchalter, w 1939 r. walczył w Samodzielnej Grupie Operacyjnej „Polesie”, następnie przebywał w obozach jenieckich Arnswalde i Murnau. Po wojnie wrócił do kraju. Początkowo związał się z PPS, następnie PZPR. Pracował w administracji rządowej - w Ministerstwie Pracy i Opieki Społecznej 1945-1948, Prezydium Rady Ministrów (od 1948 r.), szef URM 1956-1980, przewodniczący Rady Ochrony Pomników Walk i Męczeństwa 1960-1981. https://katalog.bip.ipn.gov.pl/informacje/633763 (dostęp: 26 III 2020).

${ }^{74}$ Julian Fałat (1853-1929) - polski malarz, wybitny akwarelista. Dyrektor Szkoły Sztuk Pięknych i Akademii Sztuk Pięknych w Krakowie, malował sceny rodzajowe, myśliwskie, pejzaże zimowe, portrety. Zob. Internetowy Polski Słownik Biograficzny, https://www.biogramy.pl/a/biografia/ julian-falat-malarz-wiesz (dostęp: 2 IV 2020). 
- Dopuścił do niezgodnego z przepisami gospodarowania środkami dewizowymi pochodzącymi z wpłat od myśliwych zaangażowanych $\mathrm{w}$ dokonywane odstrzały zwierzyny łownej na terenach leśnych, będących w dyspozycji URM (Łańsk [na Warmii - przyp. KL], Arłamowo [w Bieszczadach - przyp. KL]).

- Osobiście wystawił i podpisał w 1976 r. pełnomocnictwo dla prezydenta m[iasta] Katowic, w którym niezgodnie z prawdą podał, że wartość domu w Katowicach, o kupno którego ubiegał się E[dward] Gierek, została przez Gierka w całości wpłacona gotówką w kasie URM (prezydent Katowic reprezentował wobec notariusza interesy Skarbu Państwa).

- Ponosi odpowiedzialność za przekazanie z funduszu URM środków na pokrycie kosztów budowy domu dla byłego ministra spraw wewnętrznych Stanisława Kowalczyka.

- Osobiście zniszczył poważną część ewidencji i dokumentacji dotyczącej wydatków z funduszu dyspozycyjnego URM, a także należności z wpływów i wydatków dewizowych funduszu łowieckiego (sprawę przekazano do prokuratury, śledztwo umorzono ze względu na zgon Wieczorka [zmarł 30 listopada $1981 \mathrm{r}$. - przyp. KL]).

- Edward Gierek (były I sekretarz KC PZPR):

- W 1976 r. nabył na własność, aktem notarialnym, dwusegmentowy dom przy ul. Różyckiego 14a i [14]b w Katowicach, wybudowany na koszt państwa w latach 1973-1975. Koszt budowy wyniósł 21260600 zł. Większą część tej kwoty zaksięgowano w ciężar kosztów przebudowy trasy murckowskiej ${ }^{75}$ oraz w ciężar kosztów inwestycji kopalnianych. Ponad $5 \mathrm{mln}$ zł sfinansował były szef URM - min[ister] Janusz Wieczorek z funduszu dyspozycyjnego premiera.

- W 1978 r. Przedsiębiorstwo Budowlane Przemysłu Węglowego w Katowicach wybudowało dla Gierka cieplarnię-warzywnik. Koszt budowy wynoszący blisko 1,5 mln zł wliczono w ciężar kosztów wybudowanej Fabryki Domów „Sigma” w Mysłowicach.

- Przy zawieraniu aktu notarialnego w mieszkaniu Gierka, posłużono się pismem szefa URM Janusza Wieczorka, z którego wynikało, że cała należność za kupiony dom została w całości wpłacona gotówką do kasy URM przez nabywcę. Takie pismo przedłożył notariuszowi prezydent Katowic, reprezentujący Skarb Państwa. Charakterystyczne jest, że w piśmie nic nie wspomina się, jaką to sumę wpłacił do kasy URM kupujący. Szczegółowa kontrola dokumentacji finansowej w URM, jak i [sam] zainteresowany Wieczorek, nie potrafił przedstawić w tej sprawie żadnych dowodów. W akcie notarialnym podpisanym przez Stanisławę i Edwarda Gierków, prezydenta miasta, reprezentującego Skarb Państwa i notariusza nie pisze się, jaką wartość stanowi wspomniany dom. Koszt[y] sporządzenia aktu notarialnego oraz opłata skarbowa, po zastosowaniu wszelkich możliwych ulg, wyniosły 712 zł.

\footnotetext{
${ }^{75}$ Jedna z głównych arterii komunikacyjnych w Katowicach. Przebudowywana od 1975 r.
} 
Kwotę tę pokrył z własnej kieszeni prezydent Katowic ${ }^{76}$. W świetle ustaleń kontrola NIK wystąpiła do odpowiednich władz o unieważnienie z mocy prawa zawartego aktu notarialnego i ponowne przejęcie na własność Skarbu Państwa wspomnianego domu, cieplarni oraz działki ${ }^{77}$.

- Piotr Jaroszewicz (premier rządu w latach 1971-197978):

W sprawie Piotra Jaroszewicza pragnę złożyć kilka wyjaśnień:

- Po pierwsze: sprawy natury zasadniczej, odnoszące się do gospodarki, zgodnie z zapotrzebowaniem komisji zostały wcześniej przekazane na ręce przewodniczącego Grabskiego ${ }^{79}$. Nie ma więc potrzeby ponownego ich referowania, zajęłoby to dużo czasu.

- Po drugie: zarzut, że Piotr Jaroszewicz wykorzystał zajmowane stanowisko dla nieformalnego wejścia w posiadanie willi w Aninie [dzielnica Wawer w Warszawie - przyp. KL], w świetle kontroli nie znalazł potwierdzenia. Willa w Aninie stanowiła własność Skarbu Państwa. W latach [pięćdziesiątych] ${ }^{80}$, na mocy decyzji [odpowiednich - przyp. KL] władz, została ona nieodpłatnie przekazana Julianowi Tuwimowi ${ }^{81} \mathrm{w}$ dozgonne użytkowanie, po śmierci użytkownik[a], willa z powrotem znalazła się w posiadaniu Skarbu Państwa. Jaroszewicz kupił tę willę od Skarbu Państwa zgodnie z obowiązującymi przepisami, za kwotę 400 tys. zł, pochodzącą z własnych oszczędności oraz oszczędności małżonki - Alicji Solskiej-Jaroszewicz.

- Po trzecie: eksperci, którzy analizowali [dokumenty - przyp. KL] dotyczące wyceny budynku oraz zastosowanych ulg orzekli, że biorąc pod uwagę stan techniczny (duże zniszczenia), konieczny gruntowny remont - wycena została dokonana prawidłowo. Dokumentacja techniczno-finansowa na przeprowadzone roboty remontowe znajduje się $\mathrm{w}$ posiadaniu właściciela i nie budzi zastrzeżeń. Zastosowane ulgi wobec kupującego, mieszczą się w ogólnie obowiązujących przepisach, szeroko stosowanych przy sprzedaży domów i mieszkań. Dodatkowa $10 \%$ zniżka z tytułu uprawnień kombatanckich również nie budzi zastrzeżeń.

\footnotetext{
${ }^{76}$ Funkcję tę pełnił Lucjan Gajda. Zob. przyp. 83.

${ }^{77}$ Pod adresem Gierka pojawiły się także - pominięte przez Piłatowskiego - zarzuty ułatwienia swoim synom nabycia domów mieszkalnych; zob. Korupcja polskiej nomenklatury ( $Z$ tajnych akt Najwyższej Izby kontroli), „Zeszyty Historyczne” 1983, nr 64, s. 149.

${ }^{78}$ Formalnie Jaroszewicz urząd premiera sprawował do lutego $1980 \mathrm{r}$.

${ }^{79}$ Niejasne sformułowanie - nie wiadomo o jakie dokumenty chodzi. Można założyć, że Piłatowski miał na myśli informacje NIK na temat głównych kontroli, prowadzonych w minionej dekadzie w różnych działach życia gospodarczego.

${ }^{80} \mathrm{~W}$ oryginale było: 50 .

${ }^{81}$ Julian Tuwim (1894-1953) - polski poeta, tłumacz, - współtwórca grupy poetyckiej Skamandryci, w czasie II wojny światowej na obczyźnie (do 1946 r.), autor m.in. takich dzieł jak Czyhanie na Boga (1918), Bal w Operze (1936), Kwiaty polskie (1940). Zob. Internetowy Polski Słownik Biograficzny, www.ipsb.nina.gov.pl:8080/a/biografia/julian-tuwim-poeta-wiesz (dostęp: 2 IV 2020).
} 
Nie będę już mnożył [dalszych] przykładów. Można by przytoczyć ich jeszcze bardzo dużo. Sądzę jednak, że nie w tym rzecz, aby rozdrapywać zabliźnione rany.

Sądzę, że celowym będzie wskazać na niezwykle zróżnicowane reakcje osób stojących przed komisją Tadeusza Grabskiego. Byli tacy, którzy będąc w Biurze Politycznym i w rządzie nie interesowali się zagadnieniami gospodarki kraju. Całkowicie pochłaniały ich sprawy resortowe, np. obrona narodowa, funkcjonowanie organów ścigania, itp. Przytłaczająca większość usiłowała tłumaczyć przyczyny kryzysu z lat 1976-1980 czynnikami obiektywnymi, niekorzystną koniunkturą na rynkach światowych, kryzysem paliwowym, trudnościami w stosunkach handlowych wewnątrz RWPG i z ówczesnym ZSRR, itp. Tylko nieliczni wskazywali na przyczyny subiektywne zaistniałej sytuacji, próbując jednocześnie określić w tym swoją rolę.

Do nich zaliczam byłego premiera $z$ lat 1971-1979 Piotra Jaroszewicza. Swoją postawą wzbudził szacunek większości członków komisji. Składane przez niego wyjaśnienia były konkretne i bardzo rzeczowe. Precyzyjnie formułował swoje oceny sytuacji, odnoszące się do okresu pełnienia przez niego funkcji Prezesa Rady Ministrów. Z jego wypowiedzi wynikała głęboka znajomość sytuacji gospodarczej kraju i pełna za nią odpowiedzialność. Słuchając tych wyjaśnień owładnęło mną przeświadczenie, że chce on rzeczywiście pomóc komisji w głębszym zrozumieniu wewnętrznych i międzynarodowych uwarunkowań zjawisk kryzysowych w Polsce. Nie pomijał przy tym subiektywnych błędów, które popełnił rząd pod jego kierownictwem. N[a] p[rzykład] dotyczyło to części zakupionych licencji, które nigdy nie weszły do produkcji. Nadmiernego rozszerzenia frontu inwestycyjnego. Nienadążania przez budownictwo z przygotowaniem hal produkcyjnych pod instalację maszyn i urządzeń technicznych napływających z zagranicy. Opóźnienia $\mathrm{w}$ ich instalacji $\mathrm{w}$ wielu przypadkach prowadziły do utraty gwarancji na długo przed wprowadzeniem do produkcji. Złe warunki magazynowania, często na otwartych przestrzeniach, doprowadziły do całkowitego lub częściowego zniszczenia setek drogich maszyn, urządzeń i całych linii technologicznych. Za ten stan rzeczy [premier Jaroszewicz - przyp. KL] odpowiedzialność brał całkowicie na siebie. Dodać tu należy, że w sprawach tych NIK informowała wielokrotnie premiera $\mathrm{w}$ oparciu o przeprowadzone kontrole. Informacje te znajdowały się również w posiadaniu członków komisji. Ten na pozór spokojny człowiek (w gruncie rzeczy był człowiekiem impulsywnym, porywczym, często popadającym w stan wysokiego zdenerwowania), zwłaszcza $w$ jednym przypadku uzewnętrznił duże zdenerwowanie. Stało się to w momencie, gdy komisja zaczęła dyskutować nad wnioskiem o pozbawienie go odznaczeń państwowych. Energicznie podniósł się z krzesła i w pozycji stojącej, z iskrzącymi oczami, skamieniałą twarzą, podniesionym głosem zawołał: „Czy Krzyża Grunwaldu ${ }^{82}$ też chcecie mnie

${ }^{82}$ Polskie komunistyczne odznaczenie wojskowe - order (trzy klasy), ustanowione w 1943 r., zatwierdzone uchwałą Krajowej Rady Narodowej w 1944 r., nadawane do 1992 r. za bohaterskie czyny w walce zbrojnej z okupantem niemieckim. 
pozbawić?”. Spokojna odpowiedź Grabskiego, że to wysokie odznaczenie bojowe otrzymał za walkę i bohaterstwo na froncie II wojny i nie jest to przedmiotem rozważań komisji przywróciło mu spokój. Po chwili usiadł i czekał na końcowe stanowisko komisji.

Jakże diametralnie odmienne stanowisko zaprezentował Gierek. Przybył on na posiedzenie komisji z dwoma aparatami do nagrywania rozmów. Po zwróceniu mu uwagi przez Grabskiego, że obrady komisji są utrwalane na taśmie magnetofonowej oraz stenografowane i jeśli będzie chciał, będzie mógł ten materiał otrzymać, Gierek odparł: „Jeżeli nie pozwolicie, aby mój oficer ochrony mógł nagrywać przebieg obrad, to ja żadnych wyjaśnień nie będę składał!" Przewodniczący komisji wyraził zgodę, aby oficer ochrony pozostał na sali i mógł nagrywać przebieg obrad komisji.

Po zadaniu pytań przez członków komisji, Gierek przystąpił do składania wyjaśnień, które były bardzo pokrętne i niewiele wnosiły do wyjaśnienia spraw zasadniczych. Mieściły się w zasadzie w następującej konwencji: wszystko, co dobre, to jego zasługa. Wszystko, co złe, to on o tym nie wiedział, po raz pierwszy dowiaduje się o tym tu, na posiedzeniu komisji. Gierek usiłował przekonać członków komisji, że on chciał dla Polski dobrze lecz był systematycznie wprowadzany w błąd przez swoje najbliższe otoczenie. Nie informowano go o różnych słabościach, napięciach i niepowodzeniach w gospodarce. Nie informowano go o ujemnym bilansie w handlu zagranicznym ani też o szybko rosnącym zadłużaniu się naszego kraju wobec państw zachodnich. Wiadomości, które przekazywano mu w powyższych sprawach, wskazywały, że jest wszystko w porządku. Jego współpracownicy zarzucali go różnymi drobiazgami, aby w ten sposób odsuwać od spraw węzłowych dla kraju. Można było odnieść wrażenie, że Gierka otaczała grupa „spiskowców”, wobec której był on bezsilny. Gierek zdenerwował się szczególnie w momencie, gdy Grabski zażądał od niego ustosunkowania się do spraw związanych z nabyciem domu w Katowicach. Podniesionym głosem wprost krzyczał, że [on] żadnego domu w Katowicach nie kupił. Nie interesował się kosztami budowy domu ani cieplarni. Uważał, że mienie, które jest w jego posiadaniu, zostało przez rząd nieodpłatnie przekazane mu w dozgonne użytkowanie. Na moją replikę, że takiego postanowienia rządu nie ma, jest natomiast sporządzony przez notariusza i podpisany przez Stanisławę i Edwarda Gierków akt kupna - sprzedaży domu przy ul. Różyckiego 14a i [14]b w Katowicach. W imieniu Skarbu Państwa, jako sprzedający, akt notarialny podpisał prezydent m[iasta] Katowic - [Lucjan przyp. KL] Gajda ${ }^{83}$. Gierek stanowczo zaprzeczył, aby kiedykolwiek podpisywał akt kupna - sprzedaży. „Ja nie zapłaciłem złamanego grosza za ten dom, to jak mogłem go kupić? Ja sobie na to nie pozwolę!” Dopiero po odczytaniu przeze

${ }^{83}$ Lucjan Gajda (ur. 1936) - członek PZPR. Urząd prezydenta Katowic sprawował w latach 19751978. https://katalog.bip.ipn.gov.pl/informacje/11963 (dostęp: 31 X 2020). 
mnie aktu notarialnego oraz po okazaniu zainteresowanemu znajdujących się na tym akcie podpisów, przyznał, że są to podpisy żony i jego. „Podpisując ten akt, czyniłem to w przeświadczeniu, że podpisuję akt darowizny. Zabierzcie sobie ten dom!” - krzyczał. „Dajcie mi dwa pokoje z kuchnią, to mi wystarczy!” Grabski stanowczym głosem przerwał tę żenującą tyradę i zaprosił członków komisji do zabierania głosu w dyskusji. Mimo szerokiej dyskusji, wnikliwych ocen i surowych wniosków formułowanych w jej imieniu, Gierek robił wrażenie, że nic z tego nie rozumie, jego te sprawy [nie] dotyczą. Odpowiedzialność za stan polskiej gospodarki ponosi rząd, a nie I sekretarz. Gdy komisja przeszła do sformułowania wniosków o pozbawienie Gierka mandatu poselskiego, odznaczeń państwowych i przynależności do partii, uciekł się on do szantażu. Powiedział m.in.: „Wszystko, o czym tu mówiliśmy mam nagrane na taśmach, chcę wam powiedzieć, że jeżeli zajdzie potrzeba, to zwrócę się o pomoc do swoich przyjaciół za granicą".

Sądzę, że przytoczone przykłady dają pewien pogląd na pracę komisji Grabskiego oraz na powinności, które wobec niej spełniał przedstawiciel NIK.

W I połowie czerwca 1981 r. komisja Grabskiego zakończyła działalność. Opracowała sprawozdanie i wnioski dotyczące odpowiedzialności poszczególnych osób z kierownictwa partii i rządu. Materiał ten miał być przedmiotem obrad przedzjazdowego Plenum KC PZPR, które miało rozpatrzyć sprawę przynależności do partii osób odpowiedzialnych za doprowadzenie kraju do głębokiego kryzysu gospodarczego i politycznego ${ }^{84}$. Jak wiadomo z przebiegu obrad plenum, tak się nie stało. Ograniczono się tylko do wysłuchania informacji Grabskiego i na tym poprzestano, nie wyciągając żadnych konsekwencji w stosunku do winnych. Nieznane są motywy, które skłoniły kierownictwo partyjne do zajęcia takiego stanowiska. Osobiście uważam, że była to przemyślana taktyka polegająca na starannie maskowanym dystansowaniu się grupy kierowniczej PZPR od jednoznacznego odcięcia się od kryzysogennej przeszłości i ludzi za to odpowiedzialnych. Wychodzono z założenia, że opieszałość może doprowadzić do stępienia silnego naporu dołów partyjnych i opinii publicznej, żądających pociągnięcia do odpowiedzialności winnych. W ten sposób, odgrywając rolę hamulcowego, a nie lokomotywy, wąska grupa w kierownictwie dążyła do jej „rozmycia”. Zbyt jednoznaczne podejście do tej sprawy mogło [podważyć] lub co najmniej znacznie osłabić pozycje niektórych osób dzierżących od sierpnia 1980 r. ster władzy politycznej i państwowej, które przecież przez blisko 10 lat stanowiły bezpośrednie oparcie dla władzy Gierka i Jaroszewicza i ani razu nie potrafiły zdobyć się na jakiekolwiek wyrażenie swojego niepokoju lub niezadowolenia ze stopniowego

${ }^{84}$ Chodzi o XII Plenum KC PZPR, które obradowało 10 lipca 1981 r. Wśród osób, pod adresem których wysunięto wtedy zarzuty dotyczące niezgodnych z prawem inwestycji budowalnych, było 3 byłych sekretarzy KC, 23 byłych I sekretarzy komitetów wojewódzkich, 34 sekretarzy komitetów wojewódzkich, 7 wicepremierów, 18 ministrów, 56 wiceministrów, 21 wojewodów i 30 wicewojewodów; zob. PZPR a Solidarność..., s. 879. 
pogrążania się kraju w głęboki[m] kryzys[ie] gospodarczy[m] i polityczny[m]. Problem ten, nie bez racji, silnie wykorzystywał dla swojej obrony przed komisja Grabskiego Edward Gierek.

Taktyka, o której wyżej mowa nie niosła ze sobą zbyt dużego ryzyka. Była zatem bezpieczna dla jej zwolenników. Jeżeli się powiedzie, to cel zostanie osiągnięty! A jeżeli nie? To odpowiedzialność spadnie na Grabskiego, który stojąc na czele komisji i mając do dyspozycji takie dźwignie, jak NIK, organa prokuratury, itp. w sposób nieudolny przeprowadził powierzoną mu pracę. W związku z tym Plenum KC nie było w stanie pociągnąć do odpowiedzialności partyjnej osób z byłego kierownictwa partii i rządu. Dla umocnienia swoich wpływów i wiarygodności w partii, osoby, które stały do końca najbliżej Gierka i były wobec niego najbardziej spolegliwe, rozpętały na szeroką skalę, przy użyciu wszystkich dostępnych środków kampanię propagandową przeciwko „twardogłowym” w partii, którzy okopując się na starych pozycjach usiłują hamować proces reform. Na czołowych przedstawicieli [tego nurtu - przyp. KL] wyznaczono: Tadeusza Grabskiego - człowieka gruntownie wykształconego, doktora nauk ekonomicznych, legitymującego się dużą praktyką przemysłową. Był on nowym człowiekiem w kierownictwie partii. Nie ciążyły na nim błędy przeszłości ani też współodpowiedzialność za ich popełnienie. To on zdecydował się ostro skrytykować błędy w działalności partii i rządu, osobiście premiera Piotra Jaroszewicza na plenum KC w 1977 r. ${ }^{85} \mathrm{Za}$ to wystąpienie odwołany został ze stanowiska I sekretarza KW PZPR w Koninie i skierowany do pracy w jednym z zakładów przemysłowych $\mathrm{m}$ [iasta] Poznania. $\mathrm{Na}$ drugiego przedstawiciela "twardogłowych” wyznaczono Stefana Olszowskiego $^{86}$, który również odważył się skrytykować Edwarda Gierka ${ }^{87}$. Został on za

${ }^{85}$ Właściwie chodzi o XIII Plenum KC PZPR z grudnia 1978 r., gdy Grabski mówił o stawianiu „coraz wyższych wymagań przed kadrą kierowniczą” i „coraz wnikliwszym ocenianiu jej przydatności na zajmowanych stanowiskach”. Stanowisko I sekretarza w Koninie utracił kilka miesięcy później. Jego przemówienie było odtwarzane nawet podczas strajku w stoczni w Szczecinie w sierpniu 1980 r. Zob. tekst Tomasza Kozłowskiego: https://www.polityka.pl/tygodnikpolityka/ historia/1563151,2,internowanie-i-sekretarza.read?page $=181$ \&moduleId=5732 (dostęp: 27 III 2020); Dyskusja na XIII Plenum KC, „Trybuna Robotnicza”, 15 XII 1978 r., s. 3. Było to już kolejne krytyczne wystąpienie Grabskiego - pierwsze miało miejsce podczas VII Plenum KC w październiku 1977 r.; zob. J. Tejchma, Kulisy dymisji. Z dzienników ministra kultury 1974-1977, Kraków 1991, s. 282.

${ }^{86}$ Stefan Olszowski (ur. 1931) - polityk komunistyczny, działacz ruchu młodzieżowego-członekZMP i Zrzeszenia Studentów Polskich (ZSP), przewodniczący Rady Naczelnej ZSP 1956-1960, członek PZPR od 1952 r., kierownik Biura Prasy KC 1963-1968, sekretarz KC 1968-1971, członek Biura Politycznego 1970-1980 (luty) i 1980 (sierpień)-1985, minister spraw zagranicznych 1971-1976, sekretarz KC 1976-1982, ambasador w Niemieckiej Republice Demokratycznej (NRD) marzeclistopad 1980, ponownie minister spraw zagranicznych 1982-1985, od 1986 r. przebywał prywatnie w Stanach Zjednoczonych, poseł na Sejm 1969-1980 i 1981-1983. T. Mołdawa, op. cit., s. 407.

${ }^{87}$ Raczej chodzi o podważanie pozycji premiera Jaroszewicza i rządu, co miało nastąpić po objęciu przez Olszowskiego w grudniu 1976 r. funkcji sekretarza ekonomicznego KC; zob. M. Szumiło, 
to odwołany z Biura Politycznego i [stanowiska] ministra spraw zagranicznych i skierowany do pracy w dyplomacji ${ }^{88}$. Stefan Olszowski cieszył się dużym autorytetem w szerokich kręgach aktywu partyjnego.

Osoby wyżej wymienione, w odczuciu niektórych partyjnych „reformatorów” zagrażały ich pozycji. Dlatego usiłowali oni doprowadzić do ich politycznej kompromitacji w okresie przygotowań do IX Nadzwyczajnego Zjazdu PZPR. Należy przyznać, że w poważnym stopniu „reformatorzy” cel swój osiągnęli. Pomógł im w tym ogólny chaos i dezinformacja, które opanowały szeregi partyjne i dużą część delegatów oraz zręczne manipulowanie nimi podczas obrad zjazdu. W trzecim dniu obrad [tzn. 16 lipca 1981 r. - przyp. KL] kilku delegatów wystąpiło z żądaniem, aby prezes NIK Mieczysław Moczar przedłożył Zjazdowi informację o realizacji Uchwały VI Plenum KC z października 1980 r. Moczar informacji takiej nie mógł przedłożyć Zjazdowi, bo nie był do tego przygotowany, nie posiadał przy sobie żadnych materiałów. Zaproponował więc, aby informację na ten temat złożył delegatom wiceprezes NIK Władysław Piłatowski, który koordynował całość działań kontrolnych związanych z realizacją powyższej uchwały ${ }^{89}$. Propozycja została przyjęta, a Prezydium Zjazdu miało niezwłocznie określić termin jej złożenia. W następstwie tego Prezydium zobowiązało Moczara, aby natychmiast zawiadomił mnie, iż nazajutrz o godz. 9.00 rano mam poinformować delegatów w przedmiotowej sprawie. Wiadomość o tym otrzymałem od prezesa telefonicznie w nocy o godz. 0.30 (w tym dniu obrady zjazdu trwały do późnych godzin nocnych). Natychmiast udałem się do gmachu NIK i przystąpiłem do opracowania tekstu informacji, w oparciu o dostępne mi fragmentaryczne materiały znajdujące się w moim biurku. Całość materiałów znajdowała się w tajnej kancelarii, do której dostęp mogłem mieć dopiero o godz. 8.30. Pomimo tych trudności, o godz. 8.50 byłem na sali obrad zjazdu z rękopisem żądanej informacji.

O godz. 9.00 Zjazd wznowił czwarty dzień obrad [17 lipca ${ }^{90}$ - przyp. KL], ale wbrew ustaleniom, głosu mi nie udzielono. Za pośrednictwem przewodniczącego

Kierownictwo PZPR w latach 1971-1980, w: PRL na pochylni (1975-1980), red. M. Bukała, D. Iwaneczko, Rzeszów 2017, s. 41.

${ }^{88}$ Chodzi o wspomniane w przyp. 86 przejściowe usunięcie Olszowskiego z Biura Politycznego KC w lutym 1980 r. i skierowanie go jako ambasadora PRL do NRD.

${ }^{89}$ Poza tym 3 lipca 1981 r. Władysław Piłatowski wystąpił w czasie konferencji prasowej, podczas której mówił o nadużyciach popełnionych przez „ludzi władzy”. Za potwierdzone uznał zarzuty pod adresem 3422 osób. Dla aparatu partyjnego szokiem było nie tyle podanie informacji o tym, ilu było wysokich urzędników administracji państwowej (7 wicepremierów i kierowników urzędów centralnych, 56 wiceministrów i równorzędnych, 21 wojewodów), ale przede wszystkim jak wiele osób pełniło wysokie funkcje w PZPR (3 byłych sekretarzy KC, 23 I sekretarzy komitetów wojewódzkich, 34 sekretarzy komitetów wojewódzkich). Budownictwo prywatne w świetle kontroli NIK, „Dziennik Polski”, 6 VII 1981 r., s. 6.

${ }^{90}$ Możliwe, że Piłatowski pomylił daty. W literaturze przedmiotu podaje się, że wspomniane wystąpienie miało miejsce 19 lipca; zob. J. Szumski, op. cit., s. 244. 
CKKP postanowiłem wyjaśnić sobie tę sytuację z myślą, że uzyskany czas wykorzystam na dopracowanie tekstu informacji i przepiszę ją na maszynie. Po pewnym czasie otrzymałem odpowiedź, że muszę być na sali, bo w każdej chwili mogę być wezwany do zabrania głosu. Cały dzień upłynął, zanim dopiero o godz. 20.00 wezwano mnie do złożenia informacji. Fakt ten nie wymaga komentarza. Dlatego też na wstępie zwróciłem uwagę delegatów na okoliczności i czas, w jakim przyszło mi opracować rękopis przedkładanej informacji. Przedstawioną treść Zjazd przyjął $\mathrm{z}$ dużą aprobatą. A skierowane do mnie przez jednego $\mathrm{z}$ delegatów słowa podziękowania spotkały się ponownie z dużymi oklaskami, za które przyszło mi drogo zapłacić.

Po moim wystąpieniu ogłoszono przerwę. Pod koniec przerwy podszedł do mnie jeden z odpowiedzialnych pracowników KC i powiedział, żebym pozostał do końca obrad w tym dniu oraz w dniu następnym, bo mogę być „potrzebny”. Okazało się, że miał rację, bo oto po wznowieniu obrad jeden z delegatów, niezapowiedziany wcześniej i poza kolejnością, zabrał głos i skrytykował treść złożonej przeze mnie informacji. Słowa tej krytyki sala przyjęła bez aprobaty. Następnie zabrał głos jeszcze jeden $\mathrm{z}$ delegatów, zapowiedziany przed przerwą i na tym tego dnia obrady zakończono. W następnym, piątym dniu obrad [18 lipca przyp. KL] nastąpiło nowe uderzenie. Oto grupa kilku osób, wśród nich byli m.in. minister Przemysłu Ciężkiego i Maszyn Rolniczych Stanisław Wyłupek ${ }^{91}$, wiceprzewodniczący Państwowej Komisji Planowania Gospodarczego Janusz Obodowski ${ }^{92}$, prezes Głównego Urzędu Patentowego Jacek Szomański ${ }^{93}$, prezes Państwowej Komisji Cen Wojciech Prus[s] $]^{94}$, wystąpiła do Prezydium Zjazdu

${ }^{91}$ Stanisław Wyłupek (1923-2015) - urzędnik państwowy, inżynier elektryk, przez lata związany z przemysłem; członek PPR, a następnie PZPR, pracownik aparatu KC PZPR 1950-1959, dyrektor naczelny Fabryki Wyrobów Precyzyjnych w Warszawie 1959-1964, dyrektor naczelny Zjednoczenia Przemysłu Obrabiarek i Narzędzi 1964-1968, wiceminister łączności 1973-1981, minister maszyn ciężkich i rolniczych w okresie luty-lipiec 1981 r., wiceminister w ministerstwie hutnictwa i przemysłu maszynowego 1981-1982, pełnomocnik rządu do spraw koordynacji stosunków gospodarczych z ZSRR 1982-1983. T. Mołdawa, op. cit., s. 444.

92 Janusz Obodowski (1930-2011) - Urzędnik państwowy, dr nauk ekonomicznych - członek PPS, następnie PZPR, naczelnik wydziału zatrudnienia w Państwowej Komisji Planowania Gospodarczego 1953-1957, dyrektor zespołu w Komisji Planowania przy Radzie Ministrów 1968-1972, minister pracy, płac i spraw socjalnych 1980-1981, wicepremier 1981-1985, przewodniczący Komisji Planowania przy Radzie Ministrów 1982-1983, stały przedstawiciel PRL w RWPG 1983 1985, ambasador w NRD 1986-1986. Ibidem, s. 404.

${ }^{93}$ Jacek Szomański (1922-1992) - urzędnik państwowy, uczestnik powstania warszawskiego, prawnik - pracownik Polskiego Komitetu Normalizacyjnego od 1949 r., członek PZPR od 1953 r., prezes Urzędu Patentowego PRL 1970-1989. https://katalog.bip.ipn.gov.pl/informacje/640627 (dostęp: 26 III 2020).

${ }^{94}$ Wojciech Pruss (ur. 1926) - urzędnik sektora finansów państwowych, uczestnik powstania warszawskiego, członek PPS, następnie PZPR, dr nauk ekonomicznych - pracownik Narodowego Banku Polskiego (NBP) od 1946 r., dyrektor Departamentu Planowania w NBP 1968-1970, zastępca przewodniczącego Państwowej Komisji Cen od 1970 r., pełniący obowiązki przewodni- 
z pismem, w którym żądali pociągnięcia mnie do odpowiedzialności partyjnej za bezpodstawne wymienianie ich nazwisk. Prezydium Zjazdu, nie podejmując żadnych czynności, zmierzających do wyjaśnienia stanu faktycznego, podało treść pisma do wiadomości delegatów, wnioskując jednocześnie [o] przekazanie sprawy do CKKP, która miała sprawę rozpatrzyć i zająć odpowiednie stanowisko. Mimo, że prosiłem o udzielenie mi głosu dla wyjaśnienia tej sprawy, głosu mi nie udzielono, przechodząc do normalnego toku obrad. Jest to kolejny znamienny przykład inspirowania delegatów przeciwko NIK, a głównie przeciwko jej prezesowi - Mieczysławowi Moczarowi.

Kilka dni po zakończeniu obrad zjazdu, CKKP rozpatrzyła tę sprawę. Po zapoznaniu się z treścią mojej informacji, zarejestrowanej na taśmie magnetofonowej, stwierdzono, że wymieniłem wspomniane nazwiska jako przykład bezpodstawnego przypisywania różnym ludziom czynów, których oni nie popełnili! Pomimo takiego stanowiska CKKP, kierownictwo partii poleciło opracować ściśle tajną informację dla delegatów, w której po raz kolejny ugodzono w dobre imię kierownictwa NIK. O treści tej informacji ${ }^{95}$, rozesłanej przez Prezydium CKKP do I sekretarzy wszystkich KW PZPR, kierownictwo NIK dowiedziało się dopiero w listopadzie 1981 r., a więc na miesiąc przed wprowadzeniem stanu wojennego.

Jak się wkrótce okazało, wszystkie działania skierowane przeciwko NIK, zarówno w czasie obrad zjazdu, jak i po ich zakończeniu, były inspirowane przez członków kierownictwa partii. Sądzę, że mogło do tego dojść tylko za osobistą zgodą Stanisława Kani.

W czerwcu 1982 r. Kania i Barcikowski w rozmowie z Moczarem wysunęli sugestię, aby wystąpił on $\mathrm{z}$ wnioskiem o odwołanie mnie $\mathrm{z}$ funkcji wiceprezesa NIK za to, że kierując działaniami kontrolnymi, zleconymi przez VI Plenum $\mathrm{KC}$, realizowałem politykę „Solidarności”. Moczar poinformował mnie o tym po powrocie z KC. Powiedział mi, że wniosku o odwołanie mnie ze stanowiska nie złoży, gdyż nie widzi ku temu żadnych podstaw. „Takie stanowisko zająłem w rozmowie z Kanią i Barcikowskim" - dodał. Po tej rozmowie nasiliły się ataki na NIK ze strony niektórych członków kierownictwa partii. Na szczególne wyróżnienie zasłużyli sobie: członek BP Albin Siwak ${ }^{96}$, który publicznie atakował Moczara

czącego tejże Komisji 1976-1977, podsekretarz stanu w Urzędzie Cen 1982-1985, wiceminister finansów 1985-1987. https://katalog.bip.ipn.gov.pl/informacje/162216 (dostęp: 26 III 2020).

${ }^{95}$ Chodzi o „Notatkę dotyczącą wyjaśnienia zasadności odwołań osób wymienionych przez wiceprezesa NIK Władysława Piłatowskiego w informacji przedstawionej na IX Nadzwyczajnym Zjeździe PZPR" z 3 sierpnia 1981 r.; zob. J. Szumski, op. cit., s. 247.

${ }^{96}$ Albin Siwak (1933-2019) - robotnik budowlany i polityk komunistyczny, pracownik sektora budownictwa mieszkaniowego w Warszawie od 1950 r., brygadzista od 1953 r., zastępca członka i członek KC PZPR 1980-1990, członek Biura Politycznego KC 1981-1986, wiceprzewodniczący ZG Niezależnego Związku Zawodowego Budowlanych, Przemysłu Budowlanego i Spółdzielczości Mieszkaniowej, w służbie dyplomatycznej (radca ambasady w Trypolisie) 1986-1989. T. Mołdawa, op. cit., s. 422. 
oraz sekretarz KC Mirosław Milewski, który obciążał NIK odpowiedzialnością za bezpodstawne wysunięcie zarzutów przeciwko wielu uczciwym i zasłużonym działaczom partyjnym.

A jak wyglądała ta sprawa w rzeczywistości? Otóż ponowne badania kontrolno-wyjaśniające wobec nielicznych osób, które odwołały się od ustaleń kontrolnych, w pełni potwierdziły ustalenia pierwotne. Znanych jest mi zaledwie kilka przypadków, w których pierwotne ustalenia znalazły tylko częściowe potwierdzenie. Dotyczyły one w zasadzie spraw drobnych. Zdarzył się też jed[en] przypadek skierowania przeciwko mnie pozwu do Sądu Wojewódzkiego w Warszawie. W maju 1983 r., natychmiast po ukazaniu się komunikatu, dotyczącego mojego przejścia w stan spoczynku, rodzeństwo [raczej chodzi o dzieci - przyp. KL] byłego szefa URM - Wieczorka - wniosło pozew w obronie czci swojego nieżyjącego już wówczas ojca. Po kilku rozprawach sąd pozew oddalił. A w wyniku złożonej przez Wieczorków rewizji, Sąd Najwyższy utrzymał w mocy wyrok Sądu Wojewódzkiego.

W grudniu 1982 r. Mieczysław Moczar ponownie został wezwany przez Wojciecha Jaruzelskiego na rozmowę. Dano mu termin do stycznia 1983 r., aby wystąpił z wnioskiem o odwołanie mnie z funkcji wiceprezesa NIK. Generałowi Moczarowi zaproponowano w sposób kategoryczny, ażeby przeszedł do pracy na stanowisko ambasadora PRL w Jugosławii. Gdy poinformował mnie o tym, zapytałem, co zamierza zrobić. Odpowiedział krótko: „Nie! Jestem skłonny przejść na emeryturę". W lutym tegoż roku pracownicy NIK pożegnali swojego prezesa - generała Mieczysława Moczara ${ }^{97}$.

W dniu 6 maja 1983 r. Rada Państwa, z polecenia Wojciecha Jaruzelskiego, w oparciu o wniosek podpisany przez ówczesnego sekretarza KC Józefa Czyrka ${ }^{98}$, odwołała mnie również z zajmowanego stanowiska.

\footnotetext{
${ }^{97}$ Formalnie ze stanowiska prezesa NIK został odwołany przez Sejm PRL w marcu $1983 \mathrm{r}$.

${ }^{98}$ Józef Czyrek (1928-2013) - polityk komunistyczny, przez lata związany z resortem spraw zagranicznych - od 1952 r. pracownik Ministerstwa Spraw Zagranicznych (MSZ), w PZPR od 1955 r., podsekretarz stanu w MSZ 1971-1980, minister spraw zagranicznych 1980-1982, sekretarz KC 1981-1989, członek Biura Politycznego KC 1981-1989, wiceprzewodniczący Rady Krajowej Patriotycznego Ruchu Odrodzenia Narodowego 1982-1989, minister stanu w kancelarii prezydenta PRL, następnie Rzeczpospolitej Polskiej 1989-1990, poseł na Sejm 1985-1989. Ibidem, s. 343.
} 


\section{Corruption of Edward Gierek's Team. The Memories of Wladyslaw Pilatowski, Vice-President of SAO, from 1980-81 \\ (Summary)}

Władysław Piłatowski was an employee of the Supreme Audit Office (1971-83), and from 1980 on, he was the vice-president of this institution. He played a crucial role in the verification of the legality of the acquisition of building plots by the high officials of the communist party and government, conducted by the SAO in 1980 (the inspection also covered other investments, such as the construction of houses, purchases of recreational parcels and apartments). In his memories, Piłatowski presents his own view of the circumstances leading to the inspection, its various meanders, and political consequences of the making the results of the SOA inspectors public. In July 1981, many names of prominent politicians and Edward Gierek's government officials were disclosed. The communist party ruling in Poland, mainly party leaders, were shocked by this revelation. For this reason, the action of the SAO and its vice-president Piłatowski met with criticism at the Ninth PUWP Congress. As a result, he lost his position, and the process of settling with Edward Gierek's ruling team lost its momentum.

\section{Bibliografia}

\section{Źródła archiwalne}

Archiwum Akt Nowych: PZPR, 4014, 1758

Archiwum Najwyższej Izby Kontroli: Departament Prezydialny, 121/1, 126/1, 1543/11, 1543/13

\section{Źródła publikowane}

VI Plenum KC PZPR 5-6 IX (I część), 4-6 X (II część) 1980, Warszawa 1980

Dziennik Ustaw 1976, nr 12, poz. 66

Dziennik Ustaw 1980, nr 22, poz. 80

Komisja Tadeusza Grabskiego (1981), oprac. M. Jabłonowski, W. Janowski, Warszawa 2013

Korupcja polskiej nomenklatury (Z tajnych akt Najwyższej Izby kontroli), „Zeszyty Historyczne” 1983, nr 64, s. 149

NSZZ „Solidarność" w regionie łódzkim w dokumentach Stużby Bezpieczeństwa 1980-1981, oprac.

S. Pilarski, R. Rabiega, Warszawa-Łódź 2010

PZPR a Solidarność 1980-1981. Tajne dokumenty Biura Politycznego, wstęp T. Kozłowski, Warszawa 2013

Sprawozdanie z działalności Najwyższej Izby Kontroli w 1972 r., Warszawa 1973

Sprawozdanie z działalności Najwyższej Izby Kontroli w 1973 r., Warszawa 1974

Sprawozdanie z działalności Najwyższej Izby Kontroli w 1975 r., Warszawa 1976

Sprawozdanie z działalności Najwyższej Izby Kontroli w 1976 r., Warszawa 1977

\section{Prasa}

„Dziennik Polski” 1981

„Trybuna Robotnicza” 1971, 1978, 1980, 1981

\section{Pamiętniki}

Jaroszewicz P., Roliński B., Przerywam milczenie, Warszawa 1991

Pińkowski J., 1980. Horyzont przed burza, Warszawa 1993

Tejchma J., Kulisy dymisji. Z dzienników ministra kultury 1974-1977, Kraków 1991 


\section{Opracowania naukowe i popularne}

Antonić D., Corruption in Serbia, Belgrade 2006

Cenckiewicz S., Gontarczyk P., SB a Lech Wałęsa. Przyczynek do biografii, Gdańsk-WarszawaKraków 2008

Cichocki B., Jóźwiak K., Najważniejsze sq kadry. Centralna Szkoła Partyjna PPR/PZPR, Warszawa 2006

Drelich S., Postulaty gdańskie w kontekście założeń ludowego populizmu oddolnego, w: Czas przełomu. Solidarność 1980-1981, red. W. Polak, P. Ruchlewski, V. Kmiecik, J. Kufel, Gdańsk 2010, s. $23-24$

Friszke A., Rewolucja Solidarności 1980-1981, Kraków 2014

Garbal Ł, Edytorstwo. Jak wydawać wspótczesne teksty literackie?, Warszawa 2011

Johnston M., Syndromes of corruption. Wealth, power and democracy, Cambridge 2005

Karklins R., Wszystkiemu winien system. Korupcja w krajach postkomunistycznych, Warszawa 2009

Korupcja na przestrzeni wieków, Warszawa 2012

Lesiakowski K., Mieczysław Moczar „Mietek”. Biografia polityczna, Warszawa 1998

Lesiakowski K., Professional negligence, mismanagement and malpractice Polish companies in the light of Supreme Audit Office materials in the years 1976-1980, „Studia Historiae Oeconomicae” 34, 2016, s. 16

Maciejowski M., Partyjni dygnitarze w odosobnieniu, „Pamięc.pl” 2012, nr 9, s. 55

Madej K., Bezradność lub represja. Władze wobec przestępczości gospodarczej w PRL (1956-1960), Warszawa 2010

Madej K., Siermiężna i dolarowa - korupcja w PRL w latach 1956-1980, w: PRL. Trwanie i zmiana, red. D. Stola, M. Zaremba, Warszawa 2003, s. 250

Makowski G., Korupcja jako problem społeczny, Warszawa 2008

Mendras M., Rule by bureaucracy in Russia, w: Democracy and corruption in Europe, eds D. Della Porta, Y. Mény, London-Washington 1997, s. 122

Mołdawa T., Ludzie władzy 1944-1991. Władze państwowe i polityczne Polski według stanu na dzień 28 II 1991, Warszawa 1991

Piotrowski P., Sprawa wspótpracy Wojciecha Jaruzelskiego z Informacją Wojskową. Rekonesans archiwalny, „Biuletyn IPN” 2007, nr 1-2, s. 116-125

Rose-Ackerman S., Korupcja i rzady, Warszawa 2001

Seidler B., Ludzie i paragrafy, Kraków 1988

Shihata I.F.I., Corruption - a general review with an emphasis on the role of the World Bank, w: Corruption: the enemy within, ed. B. Rider, Hague-London-Boston 1999, s. 260

Skwarczyńska S., Teoria listu, oprac. E. Feliksiak, M. Leś, Białystok 2006

Szumiło M., Kierownictwo PZPR w latach 1971-1980, w: PRL na pochylni (1975-1980), red. M. Bukała, D. Iwaneczko, Rzeszów 2017, s. 41

Szumski J., Rozliczenia z ekipa Gierka 1980-1984, Warszawa 2018

Wojtkowiak Z., Źródła narracyjne, cz. 1: Pamiętnik, tekst literacki, Poznań 2003

\section{Internet}

https://katalog.bip.ipn.gov.pl/informacje/1333

https://katalog.bip.ipn.gov.pl/informacje/1816

https://katalog.bip.ipn.gov.pl/informacje/1029?katalog=4

https://katalog.bip.ipn.gov.pl/informacje/11963

https://katalog.bip.ipn.gov.pl/informacje/162216

https://katalog.bip.ipn.gov.pl/informacje/640627

https://www.biogramy.pl/a/biografia/julian-falat-malarz-wiesz

https://www.ipsb.nina.gov.pl:8080/a/biografia/julian-tuwim-poeta-wiesz 
http://orka.sejm.gov.pl/ArchAll2.nsf

https://www.polityka.pl/tygodnikpolityka/historia/1563151,2,internowanie-i-sekretarza.read?page $=181 \&$ moduleId $=5732$

\section{Inne}

Zbiory własne autora: List Władysława Piłatowskiego wraz z załącznikiem z 6 kwietnia 1994 r.

Krzysztof Lesiakowski, autor m.in. Powszechna Organizacja „Służba Polsce” 1948-1955 (2008), Strajki robotnicze $w$ Lodzi 1945-1976 (2008), Centralna Szkoła Ministerstwa Bezpieczeństwa Publicznego 1945-1947 (2017). Zajmuje się badaniami nad relacjami między komunistyczną władzą w Polsce a społeczeństwem. Pracuje na Wydziale Filozoficzno-Historycznym Uniwersytetu Łódzkiego.

Kontakt: krzysztof.lesiakowski@uni.lodz.pl 